\title{
Visceral leishmaniasis: advancements in vaccine development via classical and molecular approaches
}

\author{
Sumit Joshi ${ }^{1}$, Keerti Rawat ${ }^{1}$, Narendra Kumar Yadav ${ }^{1}$, Vikash Kumar $^{2}$, Mohammad Imran Siddiqi ${ }^{2}$ and \\ Anuradha Dube ${ }^{1 *}$
}

${ }^{1}$ Division of Parasitology, Central Drug Research Institute, Lucknow, India

2 Division of Molecular and Structural Biology, Central Drug Research Institute, Lucknow, India

\section{Edited by:}

Jesus G. Valenzuela, National Institute of Allergy and Infectious Diseases, USA

\section{Reviewed by:}

Regis Bernardo Brandim Gomes,

Centro de Pesquisas Gonçalo

Moniz-Fiocruz, Brazil

Daniela De Melo Resende,

Universidade Federal de Ouro Preto,

Brazil

\section{*Correspondence:}

Anuradha Dube, LSN 201, Leishmania Laboratory, Division of Parasitology, CSIR-Central Drug Research Institute, Sector 10, Janakipuram Extension,

Sitapur Road, Lucknow 226031, India e-mail: anuradha_dube@hotmail.com

Visceral leishmaniasis (VL) or kala-azar, a vector-borne protozoan disease, shows endemicity in larger areas of the tropical, subtropical and the Mediterranean countries. WHO report suggested that an annual incidence of VL is nearly 200,000 to 400,000 cases, resulting in 20,000 to 30,000 deaths per year. Treatment with available anti-leishmanial drugs are not cost effective, with varied efficacies and higher relapse rate, which poses a major challenge to current kala-azar control program in Indian subcontinent. Therefore, a vaccine against $V L$ is imperative and knowing the fact that recovered individuals developed lifelong immunity against re-infection, it is feasible. Vaccine development program, though time taking, has recently gained momentum with the emergence of omic era, i.e., from genomics to immunomics. Classical as well as molecular methodologies have been overtaken with alternative strategies wherein proteomics based knowledge combined with computational techniques (immunoinformatics) speed up the identification and detailed characterization of new antigens for potential vaccine candidates. This may eventually help in the designing of polyvalent synthetic and recombinant chimeric vaccines as an effective intervention measures to control the disease in endemic areas. This review focuses on such newer approaches being utilized for vaccine development against VL.

Keywords: visceral leishmaniasis, recombinant vaccines, DNA vaccines, mutant vaccines, synthetic peptide vaccines

\section{VISCERAL LEISHMANIASIS: AN UNSOLVED PROBLEM}

Visceral leishmaniasis (VL), synonymously known as kala-azar, is caused by obligate intra-macrophage protozoan parasite and is characterized by both diversity and complexity (1). The disease is prevalent in larger areas of tropical, subtropical, and the Mediterranean countries. As per WHO report, nearly 200,000 to 400,000 new cases of VL (with an average duration of several months to more than one year) occur annually with 20,000 to 30,000 deaths per year (http://www.who.int/mediacentre/factsheets/fs375/en/), which is lesser than by malaria among parasitic diseases, although its exact impact has been underestimated as an exact number of cases were never recorded. Ninety percent of the VL cases occur in Bangladesh, Brazil, India, Nepal, and Sudan. In India, $80 \%$ VL cases were only from the state of Bihar (2). A sharp ascent in the prevalence of disease is directly related to environmental changes and migration of non-immune people in endemic areas (3). Occurrence of HIV-Leishmania co-infection has placed VL as category-1 disease by WHO (4). The arthropod vector - female phlebotomine sandflies, nocturnal, and telmophagous, are responsible for the transmittance of the disease. Two species - Leishmania donovani donovani (in East Africa and the Indian subcontinent) and L. donovani infantum (in the Mediterranean region of Europe, North Africa, and Latin America) are the main causative organisms for VL (5). The parasite bears two distinct life forms: promastigote, a flagellar form, found in the gut of the vector, which is inoculated into the dermis where it is internalized by dendritic cells and the macrophages and eventually is transformed into an aflagellated amastigote form, which thrives and multiply within the phagolysosomes through a complex parasite-host interaction (6). Current control strategies for VL rely on anti-leishmanial drugs such as pentavalent antimonials, amphotericin $\mathrm{B}(\mathrm{AmB})$, miltefosine, paromomycin, etc., but they are far from satisfactory because of their cost, toxicity as well as unpleasant side effects, longer dose schedule with variable efficacies (7). The situation has further worsened with the emergence of resistance against current antileishmanial drugs in various regions of endemicity (8). Hence, in the present situation, there is an urgent need to develop an effective vaccine against VL. Although vaccination against VL has received limited attention as compared to cutaneous leishmaniasis $(\mathrm{CL})$, till date, there is no commercial vaccine against any human parasitic disease including leishmaniasis (9). The fact that healing and recovery from the active infection protects individuals from re-infection specifies the possibility of a vaccine against VL (1). An effective vaccine against the disease must rely on the generation of a strong T-cell immunity (10). Both innate (macrophages and neutrophils) as well as adaptive (B-cells, T-cells, and dendritic cells) immune response plays a significant role against Leishmania infection where macrophages play the critical role. It has been a consensus for a long time that a Th1 dominant response instead of Th2 promotes IFN- $\gamma$ production, which activates macrophages to kill parasites via nitric oxide (NO) production, ultimately leading to reduction in parasitic burden (4). The cytokine production 
and cytotoxic activity by CD8+ T-cells also contribute to the disease outcome in Leishmania infection. Initially, CD8+ T-cells were thought to play a role only during re-infection, however, they were also shown to be crucial in controlling the primary infection by skewing the responses toward Th1-type. Effector CD4+ T-cells allow activation of macrophages through various cytokines and are required for optimal host response to infection (11) whereas cytotoxic CD8 $+\mathrm{T}$-cells play a role in parasite clearance with the generation of memory responses (12).

As Leishmania parasite follows a digenetic life cycle it results in significant antigenic diversity, which ultimately hampered the passage of vaccine development against VL, therefore, the knowledge of such antigenic diversity is of utmost importance (13). Researchers have utilized several approaches for identification of potential antigens, which can be targeted as suitable vaccine candidate (Figure 1). Among them, proteomics attract the most since it addresses several unanswered questions related to microbial pathogens, including its development, evolution, and pathogenicity. Proteomic studies revealed several proteins, which are seen as potential vaccine targets offering varied levels of protection in different animal models. Recent advancement in computational biology further simplifies our knowledge regarding the in-depth study of parasite. T-cell epitope prediction via bioinformatics analysis of protein sequences has been proposed as another alternative for rationale vaccine development (14). The concept that CD8+ T lymphocytes could be important in protection and long-lasting resistance to infection has opened up a new strategy in Leishmania vaccine design known as "polytope vaccine" (15). Its major advantages include greater potency, can be controlled better, can be designed to break tolerance, can overcome safety concerns associated with entire organisms or proteins, etc.

\section{CLASSICAL APPROACHES TO LEISHMANIA VACCINE DEVELOPMENT}

LIVE/KILLED WHOLE PARASITE VACCINE

Cutaneous leishmaniasis remained the focus point for earlier attempts for vaccination made in the Middle East due to the fact

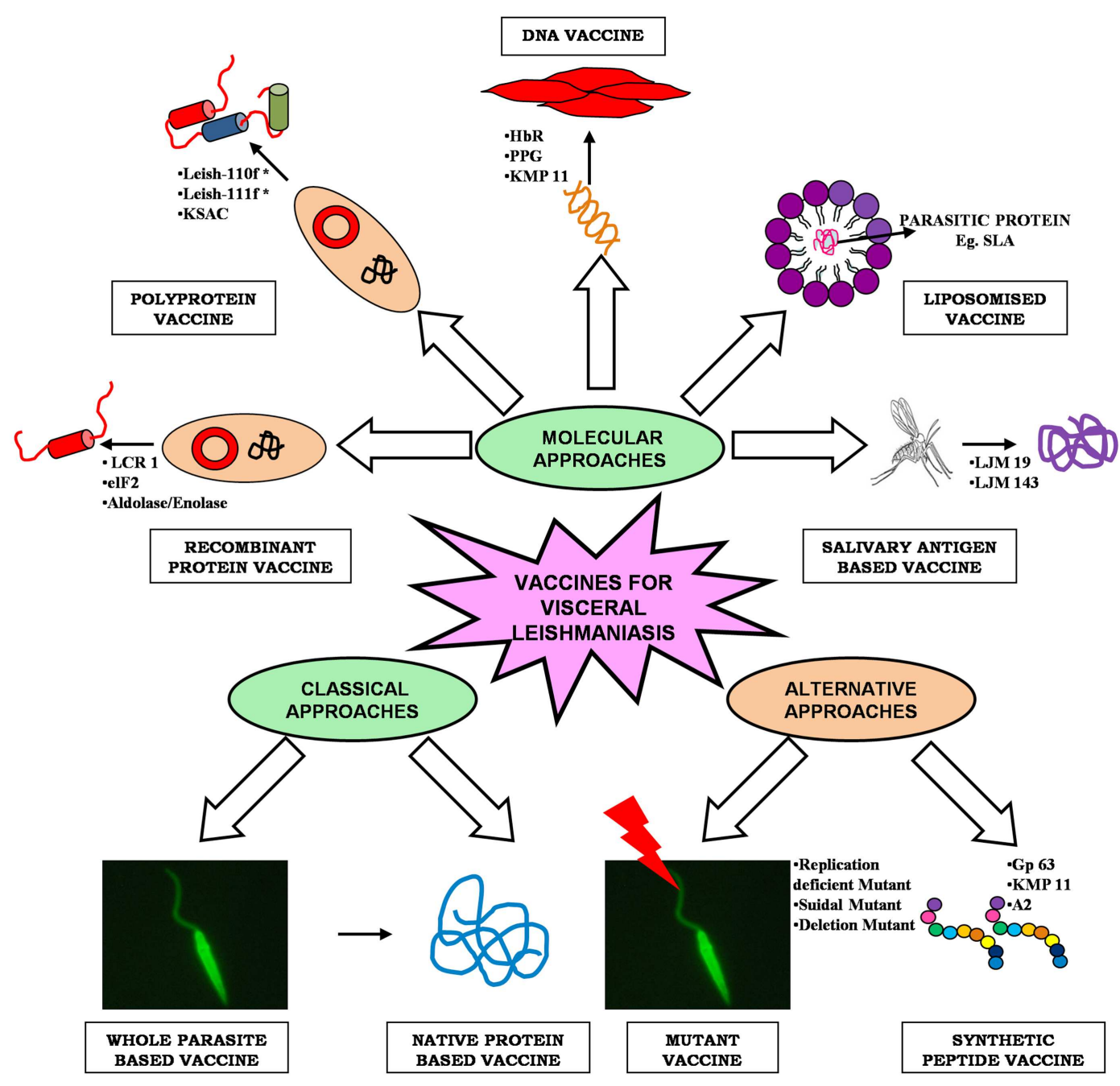

FIGURE 1 |An overview of different approaches of vaccine development for visceral leishmaniasis. 
that people who had their skin lesions healed up were protected lifelong from re-infection. Leishmanization (LZ), the deliberate inoculation of virulent parasite from the exudate of a cutaneous lesion to uninfected individuals, was successfully practiced in Western and South-Western Asia, which offers a strong immunity among individuals through the formation of self-healing lesions (16). As the researchers started culturing promastigote form of parasite in artificial media, the concept of live vaccination came into existence. A number of large-scale vaccination trials were conducted during the 1970s and 1980s in Israel, Iran, and the Soviet Union with a higher success rate. However, standardization and quality control are the major issues associated with live vaccines because parasites used for LZ losses its infectivity due to repeated sub-culturing. Therefore, the focus of vaccine development program was shifted toward killed organisms in the early $90 \mathrm{~s}$ (17). This concept was abandoned for many years due to the conflicting results obtained in the 40s. However, the vaccination trial conducted in a Brazilian population showed excellent protection with up-regulation of IFN- $\gamma$ and absence of IL-4, an indicator of long-lasting Th1-type immune response $(18,19)$. Use of whole killed parasites with or without adjuvant was proposed for both therapeutic as well as for prophylactic purposes (20).

Knowing the fact that deliberate infection of $L$. major to naive people could confer protection against subsequent VL (21) several attempts utilizing this approach was also initiated for the development of vaccine against VL. In this direction, autoclaved $L$. major (ALM) along with BCG was evaluated for its cross protection against VL (Table 1). Dube et al. (22) assessed its protective potential against $L$. donovani challenge in Indian langur monkeys in single as well as triple dose schedules where triple dose schedule was found to be more effective. Immunogenicity of the ALM + BCG vaccine was further enhanced by adsorbing ALM to alum (aluminum hydroxide), which resulted in successful vaccination against $L$. donovani infection in Indian langur monkeys (23). Encouraged with these results Khalil et al. (24) performed a double-blind randomized trial with ALM \pm BCG in human subjects against VL in Sudan. None of the evidences showed that $\mathrm{ALM}+\mathrm{BCG}$ offered significant protective immunity as compared to BCG alone. Here also, the addition of alum improved the immunogenicity of ALM, when administered intradermally (i.d.) at different doses in healthy volunteers from a non-endemic area of Sudan. Results indicated toward the safety of the vaccine mixture, which induced strong delayed type hypersensitivity (DTH) reaction with minimal side effects (25). A similar trial was conducted against canine leishmaniasis in Iran wherein a single injection of alum-ALM + BCG was found to be protective to the tune of $69.3 \%$ (26). Killed Leishmania can also be given therapeutically in combination with antimonial therapy in order to enhance cure rates and to reduce incidence of relapse (27). However De Luca et al. (28), advocated that autoclaving lowers the immunogenicity of the parasite as it destroys most of the immunogenic proteins. As such Breton et al. (29), applied another approach where they utilized $L$. tarentolae, a non-pathogenic species, to immunize BALB/c mice and found a significant protective immune response after single peritoneal injection against $L$. donovani challenge.

Though, whole parasite vaccine (either live/killed or attenuated one) offered vast array of antigens to the host immune system that induced both protective as well as non-protective responses (94), recent advent in our knowledge about the immunobiology of the Leishmania infection provided probable explanations for the failure of the first generation vaccines, which further insisted for the development of newer vaccination strategies against VL. A variety of different molecules were identified from parasite based on their abundance, surface localization, T-cell clones, screening of antigen pools/expression libraries with sera of infected animals and humans, which was further evaluated as suitable vaccine candidates leading to the production of a number of experimental vaccines against different forms of leishmaniasis over past few decades (95). In case of VL, extensive vaccination studies have not been possible due to unavailability of an appropriate animal model. Although, golden hamsters and dogs were utilized for studying the immunobiology of $L$. donovani and $L$. infantum, respectively, lack of immunological reagents and assays needed for the characterization of immune responses makes inconclusive study. In such case, a mouse model of VL has been extensively utilized since it exhibit organ-specific pathology in the liver and spleen.

\section{PROTEIN FRACTIONS BASED VACCINE}

Selection of suitable vaccine candidates seems to be a difficult task due to the multitude of antigens that has been evaluated with varied success rate depending on their formulation and the type of animal model used (20). Complete protection has not been achieved so far due to the complexity of the parasite, which generates poly-specific response (96). Therefore, different fractions of the parasite in the form of crude preparations were tested as vaccine preparation in order to draw any conclusive results (Table 1). Jaffe et al. (38) demonstrated that mice receiving promastigotederived membrane protein $\mathrm{dp} 72$ yielded a $81.1 \%$ reduction in the liver parasitemia as compared with the adjuvant controls, but there has been no further advance on the use of this antigen for the development of vaccines. Another membranous protein, FML, a glycoprotein mixture, of L. donovani in combination with saponin was assessed as vaccine in mice, hamster, and dog models of VL and found to be protective (39-42). Lemesre et al. (43) and Bourdoiseau et al. (44) utilized naturally excretory/secretory (ES) antigens of L. infantum promastigotes (LiESAp) and found them to be protective in dogs against experimental L. infantum infections. Mutiso et al. (37) delivered sonicated antigen of $L$. donovani i.d. with alum-BCG (AlBCG), MISA, or monophosphoryl lipid A (MPLA) in vervet monkeys against homologous challenge and concluded that $L$. donovani sonicated antigen containing MISA is safe and is associated with protective immune response.

A recent meta-analysis of different vaccination trials using these classical approaches had shown the lack of efficacy of these vaccines in clinical trials (97). Also, the efficacy of LZ has not been shown against VL (98). Standardization and quality control are the major problems associated with LZ, which limit its practicality and acceptability (10). Genetic variation and polymorphism in Leishmania isolates also deject this approach (99). In case of fraction based vaccines, there are issues related to purity and yield of immunogenic protein. All these lead to explore alternate approaches for generation of better vaccine. 
Table 1 | Summary of vaccines evaluated against visceral leishmaniasis.

\begin{tabular}{|c|c|c|c|c|c|c|}
\hline Vaccine delivery & Antigen & Species used & Challenge with & Host system & Remarks & Reference \\
\hline \multicolumn{7}{|c|}{ (1) WHOLE PARASITE } \\
\hline \multirow[t]{5}{*}{ (a) Killed } & $A L M \pm B C G$ & L. major & L. donovani & Indian langur & $\begin{array}{l}\text { Triple dose is more effective } \\
\text { than single dose }\end{array}$ & Dube et al. (22) \\
\hline & & & & Human & Poor efficacy $(6 \%)$ & Khalil et al. (24) \\
\hline & Alum-ALM + BCG & & & Indian langur & $\begin{array}{l}\text { Single dose is effective; } \\
\text { increased IFN- } \gamma \text { production }\end{array}$ & Misra et al. (23) \\
\hline & & & & Human & $\begin{array}{l}\text { Protective; induced strong } \\
\text { DTH response }\end{array}$ & Kamil et al. (25) \\
\hline & & & L. infantum & Dog & Moderate efficacy (69.3\%) & Mohebali et al. (26) \\
\hline \multirow[t]{7}{*}{ (b) Live-attenuated } & BT1 deleted parasite & L. donovani & L. donovani & BALB/c mice & $\begin{array}{l}\text { Protective immunity; } \\
\text { increased IFN- } \gamma \text { production }\end{array}$ & $\begin{array}{l}\text { Papadopoulou et al. } \\
\text { (30) }\end{array}$ \\
\hline & $\begin{array}{l}\text { SIR2 single allele } \\
\text { deletion }\end{array}$ & L. infantum & L. infantum & & $\begin{array}{l}\text { High IFN- } \gamma / \mathrm{IL}-10 \text { ratio with } \\
\text { increased NO production; } \\
\text { protective immunity }\end{array}$ & Silvestre et al. (31) \\
\hline & $\begin{array}{l}\text { Non-pathogenic } \\
\text { strain expressing } L . \\
\text { donovani A2 antigen }\end{array}$ & L. tarentolae & L. infantum & & $\begin{array}{l}\text { Protective response with high } \\
\text { level of IFN- } \gamma \text { production }\end{array}$ & Mizbani et al. (32) \\
\hline & $\begin{array}{l}\text { Amastigote-specific } \\
\text { protein p27 }\end{array}$ & L. donovani & $\begin{array}{l}\text { L. donovani, } \\
\text { L. major, and } \\
\text { L. braziliensis }\end{array}$ & & $\begin{array}{l}\text { Significant reduction in } \\
\text { parasite burden, Th1-type } \\
\text { response }\end{array}$ & Dey et al. (33) \\
\hline & Suicidal mutant & L. amazonensis & L. donovani & Hamster & $\begin{array}{l}\text { Effective cellular immunity; } \\
\text { increased iNOS expression } \\
\text { and IFN- } \gamma, \text { IL-12 production }\end{array}$ & Kumari et al. (34) \\
\hline & $\begin{array}{l}\text { Replication deficient } \\
\text { centrin gene }\end{array}$ & L. donovani & $\begin{array}{l}\text { L. donovani and } \\
\text { L. brazilensis }\end{array}$ & $\begin{array}{l}\text { BALB/c mice } \\
\text { and Hamster }\end{array}$ & $\begin{array}{l}\text { Protective immunity with } \\
\text { increased level of IFN- } \gamma, \text { IL-2, } \\
\text { and TNF- } \alpha \text { producing cells }\end{array}$ & $\begin{array}{l}\text { Selvapandiyan } \\
\text { et al. (35) }\end{array}$ \\
\hline & & & L. infantum & Beagle dog & $\begin{array}{l}\text { High immunogenicity; } \\
\text { increased secretion of IFN- } \gamma \text {, } \\
\text { TNF- } \alpha, \text { IL-12, and decreased } \\
\text { production of IL-4 }\end{array}$ & Fiuza et al. (36) \\
\hline
\end{tabular}

\section{(2) NATIVE PROTEIN OF PARASITE}

Parasite fraction Sonicated antigen+ AIBCG/MISA/MPLA

L. donovan

Membrane protein Dp72 and gp70-2

$\mathrm{FML}+$ saponin

\section{L. donovani \\ Vervet Monkey}

BALB/c mice
Mice

Hamster

Mice

L. donovani and Dog

L. chagasi

$\begin{array}{ll} & \text { Mice } \\ & \text { Hamster } \\ & \text { Mice } \\ & \\ \begin{array}{l}\text { L. donovani and } \\ \text { L. chagasi }\end{array} & \text { Dog }\end{array}$

\section{Good}

Good protection; elicit IFN- $\gamma$

Mutiso et al. (37) production

Dp 72 showed $81.1 \%$

efficacy; gp70-2 is

non-protective

84.4\% Protection

Palatnik et al. (39)

Protective

Palatnik et al. (40)

Increase in IgG2 and decrease Santos et al. (41)

in parasite load by $88 \%$

Effective protection; cellular Saraiva et al. (42)

and humoral response
Jaffe et al. (38) 
Table 1 | Continued

\begin{tabular}{llllll}
\hline Vaccine delivery & Antigen & Species used & Challenge with & Host system & Remarks \\
\hline Secretory protein & LiESAp & L. infantum & L. infantum & Beagle dog & $\begin{array}{l}\text { Protective; high level of IFN- } \gamma \quad \text { Lemesre et al. (43) } \\
\text { and low level of IL-4 with } \\
\text { increased NO production } \\
\end{array}$ \\
& & & $\begin{array}{l}\text { Humoral response with } \\
\text { cell-mediated immunity }\end{array}$ & Bourdoiseau et al. \\
& & & (44)
\end{tabular}

\section{(3) RECOMBINANT PROTEIN OF PARASITE}

Membrane protein LCR 1

HASPB1

A2

Soluble protein

F14

elF2

P45

PDI

TPI

TPR

Aldolase and enolase

Hypothetical

amastigote-specific

protein

Secretory protein

Secretory serine
Ribosomal

protein + saponin
L. chagasi

L. chagasi

L. donovani

L. donovani

Mice

Beagle dog

L. donovani

L. donovan

Golden hamster
Protective (65\%); increased level of IFN- $\gamma$, IL-12, TNF- $\alpha$, $\operatorname{lgG} 2$, and down-regulation of IL-4, IL-10, TGF- $\beta$

Protective ( $85 \%)$; increased level of IFN- $\gamma$, IL-12, TNF- $\alpha$, iNOS, and decreased TGF- $\beta$, IL-4

Protective (90\%); increased level of IFN- $\gamma$, TFN- $\alpha$, IL-12, and $\operatorname{lgG} 2$

Protective (90\%); increased level of IFN- $\gamma$, TFN- $\alpha$, IL-12, $\operatorname{lgG} 2$, and down-regulation of IL-10, IL-4

Good efficacy ( 60\%); increased iNOS, IFN- $\gamma$, IL-12, TNF- $\alpha$, and downregualation of IL-4, IL-10, and TGF- $\beta$

Increased expression of iNOS, IFN- $\gamma$, TNF- $\alpha$, and IL-12 with down-regulation of TGF- $\beta$, IL-4, and IL-10

Chavez-Fumagalli et al. (54) protease
Increased production of IFN- $\gamma$, IL-12, and GM-CSF

Protective; increased level of IFN- $\gamma$, IL-12, GM-CSF, and down-regulation of IL-4, IL-10

$\begin{array}{lll}\text { L. infantum chagasi } & \text { BALB/c mice } & \begin{array}{l}\text { Increased production of } \\ \text { IFN- } \gamma, \text { IL-12, and GM-CSF }\end{array} \\ & \text { BALB/c mice } \quad \begin{array}{l}\text { Protective; increased level of } \\ \text { IFN- } \gamma, \text { IL-12, GM-CSF, and } \\ \text { down-regulation of IL-4, IL-10 }\end{array} & \\ & & \text { Exhibit significant protection }\end{array}$

with lower parasite burden
Wilson et al. (45)

Stager et al. (12)

Fernandes et al. (46)

Bhardwaj et al. (47)

Kushawaha et al. (48)

Gupta et al. (49)

Kushawaha et al. (50)

Kushawaha et al. (51)

Khare et al. (52)

Gupta et al. (53)
Choudhury et al. (56) 
Table 1 | Continued

\begin{tabular}{llllll}
\hline Vaccine delivery & Antigen & Species used & Challenge with & Host system & Remarks \\
\hline \\
LiESAp-MDP & L. chagasi & L. infantum & Dog & $\begin{array}{l}\text { Efficacy }(92 \%) \text {; increased } \\
\text { IgG2, NO, and IFN- } \gamma \\
\text { production }\end{array}$
\end{tabular}

\section{(4) POLYPROTEIN}

Q protein

L. infantum

L. infantum

Dog

BALB/c mice

Leish-111f

L. major and

L. braziliensis

L. infantum

Beagle dog

Mice and

hamster

Dog

Leish-110f

L. major

L. infantum

Dog

KSAC

L. infantum or

L. infantum

L. donovani

C57BL/6 mice

production

Molano et al. (58)

Protective (90\%); positive

Molano et al. (58)

DTH response

with long-lasting IgG

response

No protection

Gradoni et al. (60)

Decreased parasite load (99.6\%); strong Th1 response (increased IFN- $\gamma$, IL-2, TNF- $\alpha$ )

Coler et al. (61)

Protection

Trigo et al. (62)

Protective with increased

IFN- $\gamma$, TNF- $\alpha$, and IL-2

Protective Th1-type response

Bertholet et al. (63)

Goto et al. (64)

\section{(5) DNA OF PARASITE}

A2 DNA

L. donovani

L. donovani

Mice

P36LACK

ORFF

KMP-11

$\mathrm{H} 2 \mathrm{~A}, \mathrm{H} 2 \mathrm{~B}, \mathrm{H} 3, \mathrm{H} 4$,

and p36 (LACK)

$\gamma \mathrm{GCS}$

UBQ-ORFF
Mice

BALB/c mice

Hamster

BALB/c mice

Dog

Mice

Mice
Significant protection with increased IFN- $\gamma$ production

Strong Th1-type response (IFN- $\gamma)$; non-protective

Significant protection (80\%) with increased IFN- $\gamma$ expression

Mixed Th1/Th2 response; protective with up-regulation of IFN- $\gamma$, TNF- $\alpha$, and IL-12 and down-regulation of IL-10

\section{Protective; mixed Th1/Th2} response (enhanced IFN- $\gamma$ and depressed IL-4 production)

Partial protection; elicit type 1 cellular response (IFN- $\gamma$ )

Protective immunity; production of specific lgG1 and IgG2a antibodies; enhanced granuloma formation

Protective; higher levels of $\mathrm{IL}-12$ and IFN- $\gamma$ and the low levels of IL-4 and IL-10

\section{Ghosh et al. (65)}

Melby et al. (66)

Sukumaran et al. (67)

Basu et al. (68)

Bhaumik et al. (69)

Saldarriaga et al. (70)

Carter et al. (71)

Sharma and Madhubala (72) 
Table 1 | Continued

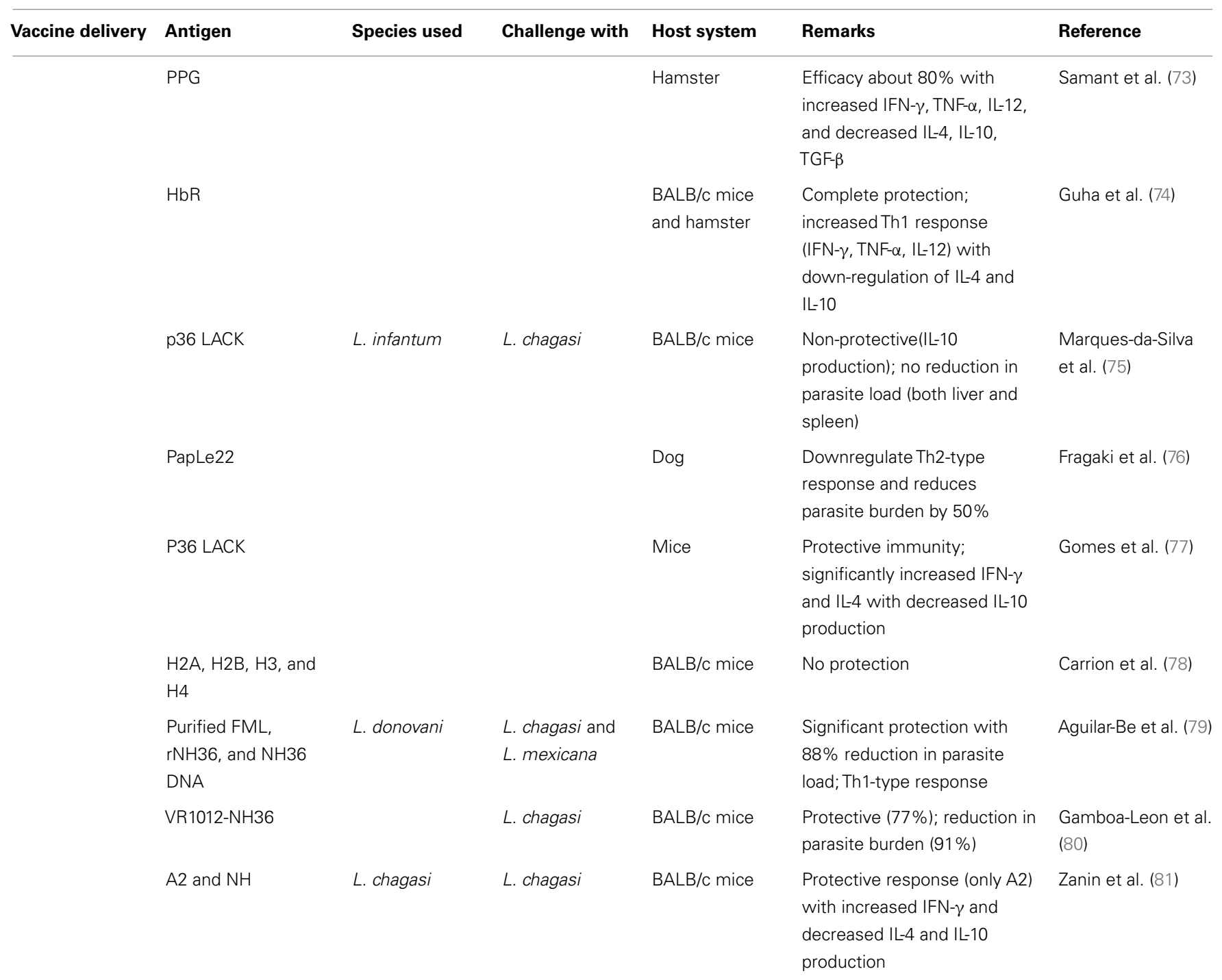

(6) RECOMBINANT PROTEIN + DNA

ORFF (HPB)

L. donovani

L. donovani

GP63 as

heterologous prime

boost (HPB)

Virus expressing

LACK antigen

(WRp36 or MVAp36)

LACK

Type I (cpb) and

II (cpa)

\section{L. infantum \\ L. infantum \\ BALB/c mice}

Dog

BALB/c mice
BALB/c mice

Protective; reduction in parasite load (75-80\%) with increased IgG2a and IFN- $\gamma$ production

Enhanced IFN- $\gamma$, IL-12, NO, $\operatorname{lgG} 2 \mathrm{a} / \operatorname{lgG} 1$ ratio, and reduced IL-4 and IL-10

Protective; significant level of IFN- $\gamma$ and TNF- $\alpha$

Moderate protection (60\%); increased level of IL-4 and IFN- $\gamma$

Protective; strong Th1 response (higher level of IFN- $\gamma /$ IL-5 ratio)
Tewary et al. (82)

Mazumder et al. (83)

Dondji et al. (84)

Ramiro et al. (85)

Rafati et al. (86) 
Table 1 | Continued

\begin{tabular}{llllll}
\hline Vaccine delivery & Antigen & Species used & Challenge with & Host system & Remarks \\
\hline CP type I and II & & L. donovani & Dog & $\begin{array}{l}\text { Increased IFN- } \gamma \text { expression } \\
\text { and IgG, IgG2 level with } \\
\text { strong DTH response }\end{array}$
\end{tabular}

\section{(7) LIPOSOMISED DELIVERY OF PARASITE PROTEINS}

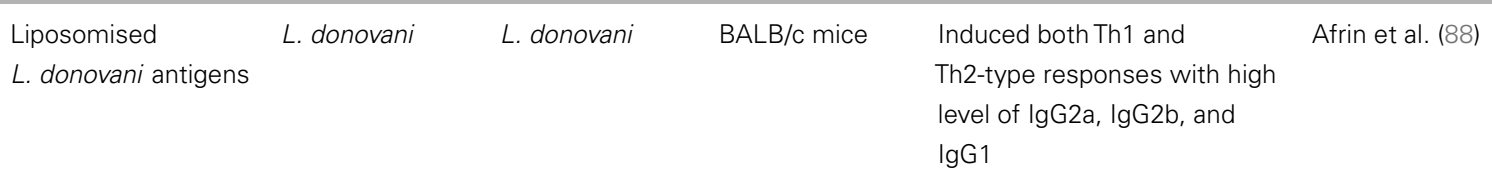

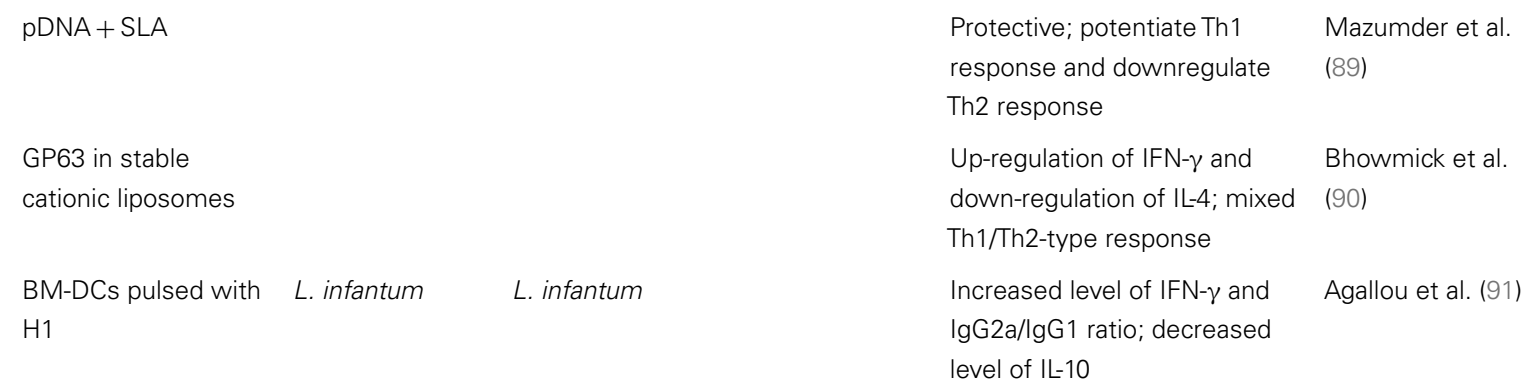

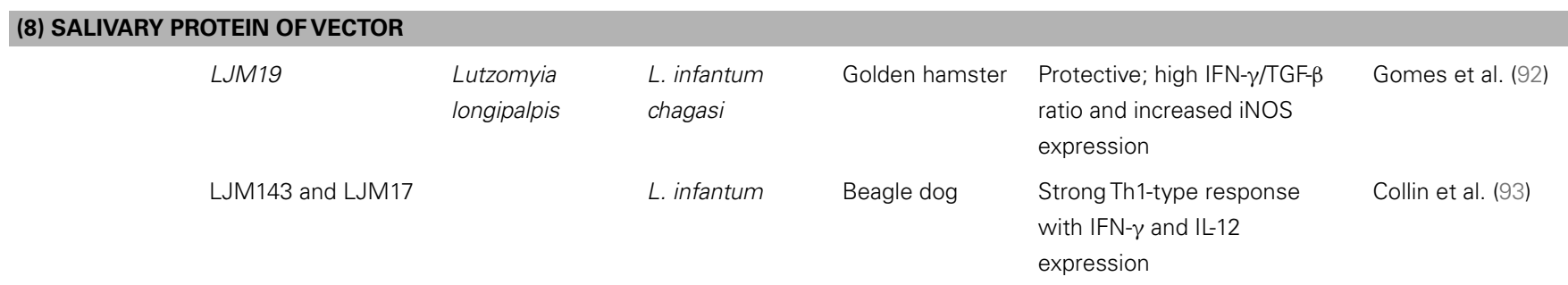

ALM, autoclaved L. major; BCG, Mycobacterium bovis bacillus Calmette Guerin; BT1, biopterin transporter; SIR2, silent information regulatory 2; AIBCG, alum-BCG;

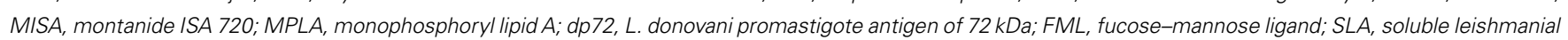

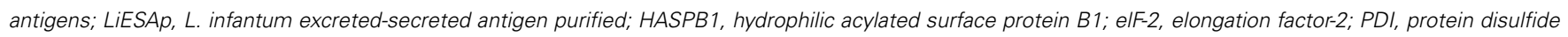

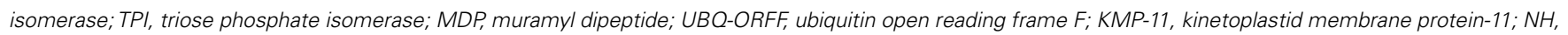
nucleoside hydrolase; LACK, Leishmania homolog of receptors for activated C-kinase; $\gamma$ GCS, gamma-glutamyl cysteine synthetase; PPG, proteophosphoglycan; HPB, heterologous prime boost; HbR, hemoglobin receptor; CP, cysteine proteinase; BM-DCs, bone marrow-dendritic cells; TPR, trypanothione reductase.

\section{MOLECULAR APPROACHES TO LEISHMANIA VACCINE DEVELOPMENT RECOMBINANT PROTEIN VACCINE}

With the advancement in recombinant DNA technology, several leishmanial molecules, either species or life cycle stage specific, were extensively studied as a promising vaccine candidate in the form of recombinant proteins. The major advantages associated with these proteins are in terms of purity as well as yield. Numerous proteins were examined against the cutaneous form of diseases, which were later examined against VL when found suitable. LCR1, A2, HASPB1 are the major membrane protein, which was made recombinant and were tested against experimental VL. Wilson et al. (45) identified specific parasite antigens LCR1 from the amastigote stage of the L. chagasi that stimulate IFN- $\gamma$ production and provided partial protection against homologous challenge directing its possible utility in a subunit vaccine. Stager et al. (12) confirmed the role of recombinant hydrophilic acylated surface protein B1 (HASPB1) in protection against $L$. donovani challenge in mice. Fernandes et al. (46) investigated the protective immunity of recombinant A2 protein with saponin against L. chagasi infection in dogs where partial protection was noticed with significantly increased IFN- $\gamma$ and low IL-10 levels (Table 1).

However, several proteins from the soluble fractions of promastigotes stage were also found to be a potent Th 1 stimulatory by Kumari et al. (100, 101), which were further developed as recombinant molecules such as protein disulfide isomerase (PDI), triose phosphate isomerase (TPI), elongation factor-2 (elF-2), aldolase, enolase, P45, trypanothione reductase (TPR), etc. Kushawaha et al. $(48,50,51)$ studied the immunogenicity of LelF-2, TPI, and PDI of L. donovani in PBMCs of cured Leishmania-infected patients and hamsters where they found Thl-type cytokine profile (production of IFN- $\gamma$, IL-12, and TNF- $\alpha$ but not IL- 4 or IL-10) with a remarkable increase in IgG2 and considerable protection. Gupta et al. $(49,53)$ reported p45, enolase, and aldolase as a potential vaccine candidate with considerable prophylactic efficacy to the tune of $85-90 \%$ with an increased mRNA expression of iNOS, IFN- $\gamma$, TNF- $\alpha$, and IL-12 and decrease in TGF- $\beta$ and IL4. Vaccination with $\mathrm{rLdTPR}+\mathrm{BCG}$ provided considerably good 
prophylactic efficacy $(\sim 60 \%)$ against $L$. donovani challenge in hamsters well supported by the increased inducible NO synthase mRNA transcript and Th1-type cytokines IFN- $\gamma$, IL-12 and TNF- $\alpha$ and downregulation of IL-4, IL-10 and TGF- $\beta$ (52). Several other proteins from soluble lysate were also evaluated as recombinant vaccines against VL. For example, recombinant F14 and ribosomal proteins offered partial protection in hamster and BALB/c mice against L. donovani/L. chagasi challenges (47, 54). Among the proteins from amastigote stage, recently, a hypothetical Leishmania amastigote-specific protein (LiHyp1) was reported to offer protection via IL-12-dependent production of IFN- $\gamma$ mainly by CD4+ T-cells (55).

Fewer recombinant ES molecules like cysteine proteinases, serine proteases, etc., were also tested as potential vaccine molecule against experimental VL. Lemesre et al. (57) combined ES antigens of LiESAp with muramyl dipeptide (MDP) and found 100\% protection in dogs with increased IgG2 and IFN- $\gamma$ level against homologous challenge. In vivo studies of Choudhury et al. (56) in $\mathrm{BALB} / \mathrm{c}$ mice confirmed serine protease as a potential vaccine candidate.

\section{POLYPROTEIN VACCINE}

Due to the genetic polymorphism in the mammalian immune system, a multicomponent vaccine thought to elicit a better protective immune response (64). Therefore, multicomponent or polyprotein preparations such as Q protein, Leish-111f, Leish-110f, KSAC, etc., came into existence that had been demonstrated to afford better protection against experimental VL. Among these, Q protein containing five genetically fused antigenic determinants from Lip2a, Lip2b, H2A, and P0 proteins, was initially assessed along with either BCG or CpG-ODN in mice and dogs $(58,59)$ against L. donovani challenge. Results showed 90\% protection with $\mathrm{Q}$ protein + BCG in dogs with strong DTH response while Q protein + CpG-ODN motifs were able to induce a long-lasting IgG response in mice. Lately, a phase III trial was conducted in dogs with another potent single polyprotein - Leish-111f, composed of L. major homolog of eukaryotic thiol specific antioxidant (TSA), the L. major stress-inducible protein-1 (LmSTI-1), and the $L$. braziliensis elongation and initiation factor (LeIF), which was found to be ineffective against L. infantum challenge (60). However, when Leish-111f was combined with adjuvant MPLAstable emulsion (MPL-SE) a significant protection was achieved against experimental $L$. infantum infection in mice and hamsters (61) as well as in dogs (62) with reduction in parasite burden and a cytokine profile indicative of Th1-type immune response. Later on, a new formulation of Leish-111f vaccine - viz Leish-110f was prepared after removal of His-tag, due to the manufacturing and regulatory purposes (102) and was evaluated for its prophylactic potential with different adjuvants [natural (MPL-SE) or synthetic (EM005) toll-like receptor 4 agonists]. This vaccine was also found to be protective, generating good humoral and cellular responses (63). Another defined polyprotein vaccine - KSAC utilizing four proteins, namely, kinetoplastid membrane protein-11 (KMP-11), SMT, A2, and CPB was developed against VL which, along with MPL was found to be immunogenic and offer significant protection against L. infantum challenge in mice (64).
Among all these polyprotein vaccines, Leish-110f is under clinical trial in Indian population and the outcome of this vaccination trial is yet to be seen.

\section{DNA VACCINES}

Besides proteins, DNA had also been extensively utilized as a means of vaccine delivery, which reformed the area of vaccinology. Here, genes encoding the target proteins are cloned into a mammalian expression vector, which is injected either intradermally or intramuscularly leading to induction of Th1 responses, resulting in strong cytotoxic T-cell immunity. Safety, stability, long-term protection, ease of administration, and cost effectiveness are the major issues associated with this form of vaccine delivery. Several molecules were evaluated using this approach such as A2, PapLe22, P36LACK, ORFF, KMP-11 proteophosphoglycan (PPG), etc., in different animal models with significant level of protection. A2 (65) and ORFF (67) when administered as a DNA vaccine were found to be significantly protective in BALB/c mice against VL, which induced both humoral and cellular immune responses. However, mice immunized with truncated $24-\mathrm{kDa}$ LACK antigen, which, though, generated a robust parasite-specific Th1 immune response (IFN- $\gamma$ but not IL-4), did not confer any protection in BALB/c mice (66). PapLe22, another protein, was assessed in the golden hamster by Fragaki et al. (76) experienced down-regulation of Th2 response and half reduction of parasitic episodes in blood circulation. The potential of a p36 (LACK) DNA vaccine was evaluated in BALB/c mice against L. chagasi wherein no reduction in parasite load (liver and spleen both) was observed, possibly due to IL-10 production (75). On the other hand, Aguilar-Be et al. (79) reported significant protection with the NH36-DNA vaccine against $L$. chagasi in $\mathrm{BALB} / \mathrm{c}$ mice with $88 \%$ reduction in parasite load and with two to fivefold increase in IFN- $\gamma$ producing CD4+ T-cells confirming Th1-type immune response. Further, Gamboa-Leon et al. (80) used garlic extract with NH36-DNA vaccine, which did not reduce parasite load, but increased survival $(100 \%)$ with non-specific enhancement of IFN- $\gamma$. In an another interesting study, the efficacy of intranasal (i.n.) vaccination with pCIneo-LACK against VL in BALB/c mice was assessed wherein significant reduction in parasite burden was noticed in both liver and spleen along with significantly increased IFN- $\gamma$ and IL-4 level with decreased IL-10 production (77). Basu et al. (68) and Bhaumik et al. (69) utilized KMP-11 for DNA vaccine in hamsters and $\mathrm{BALB} / \mathrm{c}$ mice, respectively, where they found significant protection with the mixed Th1/Th2 response (surge of IFN- $\gamma$, TNF- $\alpha$, and IL12 with extreme down-regulation of IL-10). In another study by Samant et al. (73), vaccination with DNA-encoding N-terminal domain of the PPG gene in golden hamsters yielded $80 \%$ protection against the L. donovani challenge with generation of Th1 type of immune response. Recently, Guha et al. (74) showed that immunization with hemoglobin receptor (HbR)-DNA induces complete protection against virulent $L$. donovani infection in both $\mathrm{BALB} / \mathrm{c}$ mice and hamsters with an up-regulation of IFN- $\gamma$, IL-12, and TNF- $\alpha$ with concomitant down-regulation of IL-10 and IL-4.

Several enzymes related to protection against oxidative stress were also shown to be better vaccine targets in Leishmania as well as in other parasitic diseases. Carter et al. (71) and Sharma and Madhubala (72) vaccinated mice with pVAX $\gamma$ GCS (gamma-glutamyl 
cysteine synthetase) and UBQ-ORFF, respectively, which resulted in a protective response to increased levels of IL-12 and IFN- $\gamma$ and the lower levels of IL-4 and IL-10 confirming Th1-type response.

Several workers utilized different antigens in the combinatorial approach in order to enhance the efficacy and protective response of different antigens. Zanin et al. (81) immunized mice with a $\mathrm{NH} / \mathrm{A} 2$ DNA vaccine resulted in increased IFN- $\gamma$, IL-4, and IL-10 levels associated with edema and increased parasite loads. Das et al. (103) very recently have developed a DNA vaccine using conserved proteins from various Leishmania species and found to be immunogenic inducing CD4+ and CD8+ T-cell responses in genetically diverse human populations of different endemic regions.

\section{HETEROLOGOUS PRIME BOOST VACCINE}

Different researchers utilized another strategy known as heterologous DNA-prime protein-boost (HPB) approach for some VL vaccine antigens such as ORFF, cysteine proteinases, GP63, etc., which have also shown success but are yet to reach the level of clinical trials. Ramiro et al. (85) observed $60 \%$ protection in dogs immunized with DNA-LACK prime/rVV-LACK boost against $L$. infantum challenge. Since the immune response in a canine model differs significantly from murine and human hosts, Dondji et al. (84) and Tewary et al. (82) conducted similar studies using the murine intradermal model for VL and found comparable levels of protection. With another combination of cysteine proteinases DNA/protein along with ORFF DNA/protein against experimental VL, Rafati et al. $(86,87)$ observed that vaccination mainly elicited antigen-specific IgG2a antibodies, suggesting the induction of a Th1 immune response. Very recently, Mazumder et al. (83) evaluated a membrane protein, GP63 in BALB/c mice and found robust cellular and humoral responses correlating with durable protection against $L$. donovani challenge.

\section{LIPOSOMISED DELIVERY OF PARASITE PROTEIN}

Liposome formulations have been adopted as a drug delivery system against Leishmania infection so as to induce an elevated immune response owing to their adjuvant property (104) thus can offer a new approach to the development of VL vaccines wherein it may induce a sustained Th1 immune response. This approach using L. donovani promastigote membrane antigens (LAg) encapsulated in positively charged liposomes were found to induce significant protection against experimental VL by Afrin et al. (88). Later, a study conducted by Mazumder et al. (89) showed increase in protective efficacy in animal against homologous challenge with $L$. donovani when vaccinated with both soluble leishmanial antigens (SLA) and non-coding plasmid DNA (pDNA) bearing immunostimulatory sequences (ISS), co-entrapped in cationic liposomes. In another study, using liposomised recombinant membranous protein - GP63 of L. donovani, there was a long-term protection against $\mathrm{VL}$ in $\mathrm{BALB} / \mathrm{c}$ mice (90). Recently, vaccination with bone marrow-derived dendritic cells (BM-DCs) - a new delivery system, pulsed with L. infantum histone $\mathrm{H} 1$ against homologous challenge, Agallou et al. (91) demonstrated antigen-specific splenocyte proliferation with increased IFN- $\gamma$ and decreased IL-10 production confirming Th1-type immune response.

\section{SANDFLY'S SALIVARY ANTIGEN AS VACCINE}

Salivary proteins of vector-sandfly also fetch attraction as a suitable anti-VL vaccine candidates. They received little attention in spite of the fact that salivary proteins from the vector are also delivered to the host during natural transmission of the pathogen and sometimes found immunomodulatory for the host (20). Several salivary proteins of Phlebotomus spp. and Lutzomyia spp. such as PpSP15, maxadilan, LJM17, LJM19, and LJM143 have been reported as potent immunogens inducing lymphocytic infiltration with up-regulation of IFN- $\gamma$ and IL-12 $(92,93)$. Although, these proteins conferred protection against CL $(105,106)$ they were also assessed for their immunogenicity as well as a protective response against VL. LJM19, an $11 \mathrm{kDa}$ protein, was found to be protective with higher expression of IFN $-\gamma$ and a strong DTH response in a hamster model (92). Similarly, immunization with other two salivary proteins - LJL143 and LJM17 generated strong Th1 responses in dogs with distinct cellular infiltration of CD3 + lymphocytes and macrophages (93). Therefore, these proteins may further be explored in conjunction with potent parasite proteins for vaccination studies.

Despite these different approaches offer a variable degree of efficacy, several problems still hampers its feasibility due to variations in immunogenicity and due to genetic variation in host as well as in pathogen (99). Therefore, despite of numerous recombinant proteins that have been suggested as potential vaccine candidates, to date barely few have reached to clinical trials (107). Similarly, DNA vaccine faces problems in terms of demonstration of safety and efficacy in humans in clinical trial (99).

\section{NEWER ALTERNATIVE STRATEGIES FOR DEVELOPING ANTI-LEISHMANIAL VACCINE LIVE MUTANT VACCINE}

Attenuation of virulent Leishmania parasites through defined genetic alteration is a new area in vaccine research since the perception of vaccination suggests that the more similar a vaccine is to the natural disease, better is the generation of protective immune response (108). Poor long-term immunity is the major issue with various recombinant vaccines tested so far while whole cell killed vaccines showed variable efficacy. Consequently, live-attenuated vaccine attracts the immunologists, since, it offers a complete milieu of antigens to the antigen presenting cells (APCs), therefore, providing an optimal polarization of CD4+ T-cells, resulting in better immune response (109). Also, they assure persistence of antigen that may allow the generation of antigen-specific effector and memory cells, which react immediately following infection (110). However, till date, only limited attenuated strains have been tested with various outcomes. Earlier construct generated by gene replacement was $d h f r-t s-$ and $l p g 2$ - mutants of L. major and $L$. mexicana (111) that were excluded as future Leishmania vaccines due to some inherent problem, but still they did open the door for live-attenuated vaccine against VL. Papadopoulou et al. (30) inactivated the L. donovani biopterin transporter BT1 by gene disruption that elicits protective immunity in mice against a $L$. donovani challenge (Table 1). However, Silvestre et al. (31) inactivated one allele of SIR2 in L. infantum, which elicits complete protection in $\mathrm{BALB} / \mathrm{c}$ mice with generation of specific anti-Leishmania IgG antibody subclasses and increased IFN- $\gamma / \mathrm{IL}-10$ ratio indicating both 
type 1 and type 2 responses. Mizbani et al. (32) stably expressed the L. donovani A2 antigen in L. tarentolae to check its protective efficacy in BALB/c mice against L. infantum. Results showed increased production of IFN- $\gamma$ followed by reducing levels of IL- 5 when administered intraperitoneally indicates potential Th1 immune response. In contrast, intravenous injection elicited a Th2-type response, characterized by higher levels of IL- 5 and high humoral immune response, resulting in a less efficient protection.

Recent investigations have established that tumor cells treated in vitro by photodynamic therapy (PDT) can be used for generating potent vaccines against cancers of the same origin. Leishmania, naturally residing in the phagolysosomes of macrophages, is a suitable carrier for vaccine delivery. Genetic complementation of Leishmania to partially rectify their defective heme-biosynthesis renders them inducible with delta-aminolevulinate to develop porphyria for selective photolysis, leaving infected host cells unscathed. Delivery of released "vaccines" to APCs is thus expected to enhance immune response, while their self-destruction presents added advantages of safety. Such suicidal L. amazonensis was found to confer immunoprophylaxis and immunotherapy on hamsters against L. donovani (34).

Centrin, a growth regulated gene was deleted from the amastigote stage of the L. donovani parasite and was subjected to evaluation of its prophylactic potential (112). The $\mathrm{LdCen}^{-/-}$parasite was found to be safe and protective in mice and hamsters against virulent challenge (35) and is under exploration for further development as potential vaccine against VL. Fiuza et al. (36) presented an immunogenicity profile of $\mathrm{LdCen}^{-1-}$ in dogs and showed increased antibody production and amplified lymphoproliferative response. Further, $\mathrm{LdCen}^{-/-}$vaccinated dogs showed higher frequencies of activated CD4 + and CD8 + T-cells, IFN- $\gamma$ production by CD8+ T-cells, increased secretion of TNF- $\alpha$ and IL-12/IL23 p40 and decreased secretion of IL-4. Very recently, Dey et al. (33) have demonstrated another knock out - Ldp27 (-/ - ) parasites to be safe and can provide protective immunity against both homologous and heterologous challenge with stimulation of both Th1type CD4+ and CD8+ T-cells. Since, effector T-cell population requires continuous stimulation for excellent protection; it can be well accomplished through live-attenuated vaccines. Although, there are certain issues associated with these vaccines such as probable reversal to virulence, reactivation in immune compromised individuals, manufacturing considerations, restraint to their usage in clinical studies due to the presence of antibiotic resistance genes used as selective markers during the steps of gene deletion, etc., the two-step approach, i.e., gene deletion with parasite selection and excision of the antibiotic gene cassette offers a promising way toward the generation of a safe live-attenuated vaccine. Thus, all these approaches pave the way for the development of newer generation of vaccine, which would rather be safer, provide longlasting immunity and meet both scientific as well as regulatory standards.

\section{SYNTHETIC PEPTIDE VACCINE}

Recent developments in blending of bioinformatics with vaccinology has revolutionized and expedited this area. Sequencing of large number of pathogen genome and increase in nucleotide and protein sequence databases accelerate the pace of vaccine development program. Although, killed or attenuated parasites are utilized for most of the existing vaccines, protective immune response is more often triggered by small amino acid sequence (peptides). More recent bioinformatic approaches utilizes number of algorithms for predicting epitopes, HLA-binding, transporter of antigen processing (TAP) affinity, proteasomal cleavage, etc., in order to explore the use of peptide epitopes with the highest probability of inducing protective immune responses. Generation of synthetic polyvalent peptide vaccine requires better understanding of T- and B-cell epitopes in the microorganism's proteins and their interaction with major histocompatibility (MHC) or HLA complexes. The basis of using such peptide epitopes arises from the screening of hundreds of overlapping synthetic peptides, which revealed that only a small number of regions in a protein are immunogenic and capable of provoking humoral as well as cellular immune responses. Synthetic peptide vaccines offer several advantages over other vaccine types like absence of any potentially infectious material, ability to include multiple epitopes, minimization of the amount and complexity of an antigen, economical scale up and decreased chance of stimulating a response against self-antigens.

T-cell epitopes are presented on APC surface where they interact with MHC molecules in order to induce immune response. They can be categorized as conformational or linear, depending on their structure and integration with the paratope. One of the key issues in T-cell epitope prediction is the prediction of MHC binding as it is considered a pre-requisite for T-cell recognition. All T-cell epitopes are good MHC binders, but not all good MHC binders are T-cell epitopes. For epitope prediction, generally two methods are adopted, first, sequence based that analyze protein sequences and second, structure based method using three-dimensional protein structures. Whether the predicted epitopes interact with paratope or not can also be assessed by using computational tools, which determines protein-protein interactions that helps in designing novel vaccines. Several strategies such as genomic databases, evolutionary relationships, threedimensional structure of proteins, presence of specific protein domains, primary structure of proteins, etc., have been applied to knowhow novel interacting partners in order to validate the presumed interactions. Due to the availability of epitope mapping and binding prediction algorithms, several workers have applied different bioinformatic approaches to design synthetic peptide vaccines against several parasitic diseases. In case of malaria, there have been nine clinical trials from 2000 to 2009 utilizing synthetic peptide vaccines, which target the pre-erythrocytic and erythrocytic stages of the Plasmodium falciparum, with encouraging results (113). Similarly, this approach has also been utilized in other parasitic diseases such as Toxoplasma (114), Trypanosoma (115), etc.

In case of Leishmania, several proteins like glycoprotein 63 (GP63), KMP-11, amastigote virulence factor (A2), lipophosphoglycan (LPG), cysteine proteinase, etc., both from promastigote as well as amastigote form were screened for determination of potential antigenic peptides for generation of peptide vaccine (Table 2).

\section{Glycoprotein 63}

GP63 also known as leishmanolysin, is the most widely studied protein, which is highly conserved among all leishmanial species. 
Table 2 | Summary of peptide vaccines evaluated against leishmaniasis

\begin{tabular}{|c|c|c|c|c|c|c|c|c|}
\hline Protein(s) & Spp. used & $\begin{array}{l}\text { Epitopes } \\
\text { (no. of amino } \\
\text { acid residues) }\end{array}$ & $\begin{array}{l}\text { Prediction tool(s) } \\
\text { utilized }\end{array}$ & $\begin{array}{l}\text { Challenge } \\
\text { with }\end{array}$ & Dose and route & Host system & Immune response & Reference \\
\hline \multirow[t]{7}{*}{ GP63 } & L. major & $\begin{array}{l}\text { PT 1-4; PT 6-8 } \\
\text { (12-16 residues) }\end{array}$ & Predictive algorithm & L. major & $\begin{array}{l}100 \mu \mathrm{g} \text { (each) }+8 \% \\
\text { poloxamer } 407 ; \mathrm{SC}\end{array}$ & $\mathrm{BALB} / \mathrm{c}$ mice & $\begin{array}{l}\text { Proliferation of } \mathrm{CD}^{+} \\
\text {Th1 sub-set cells } \\
\text { PT3 showed } \\
\text { immunoprotection }\end{array}$ & Jardim et al. (116) \\
\hline & & $\begin{array}{l}24 \text { Partially } \\
\text { overlapping peptides } \\
\text { (12-35 residues) }\end{array}$ & AMPHI algorithm & L. major & $\begin{array}{l}100 \mu \mathrm{g}+100 \mu \mathrm{g} C \text {. } \\
\text { parvum/entrapped } \\
\text { within liposomes; } \\
\mathrm{SC} / \mathrm{IV}\end{array}$ & $\begin{array}{l}\mathrm{CBA} \text { and } \mathrm{BALB} / \mathrm{C} \\
\text { mice }\end{array}$ & $\begin{array}{l}\text { Induction of T-cell } \\
\text { response; classical DTH } \\
\text { reactivity and secretion } \\
\text { of IL-2 and IFN- } \gamma \\
\text { p146-171 and p467-482 } \\
\text { induces significant } \\
\text { host-resistance }\end{array}$ & Yang et al. (117) \\
\hline & & $\begin{array}{l}\text { P154 and P467 (16 } \\
\text { residues) }\end{array}$ & AMPHI algorithm & L. major & $50 \mu \mathrm{g} ; \mathrm{IP}$ or SC & CBA mice & $\begin{array}{l}\text { Thl type cytokine } \\
\text { responses } \\
\text { Secretion of IL-2, IFN- } \gamma \text {, } \\
\text { and GM-CSF }\end{array}$ & $\begin{array}{l}\text { Frankenburg et al. } \\
\text { (118) }\end{array}$ \\
\hline & & PT3 (16 residues) & Predictive algorithm & L. major & $\begin{array}{l}100 \mu \mathrm{g}+8 \% \\
\text { poloxamer 407; SC }\end{array}$ & $\mathrm{BALB} / \mathrm{c}$ mice & Long-lasting protection & Spitzer et al. (119) \\
\hline & & $\begin{array}{l}\text { MHC class } \\
\text { II - restricted } \\
\text { peptides (AAR, AAP, } \\
\text { ASR) (15 residues) }\end{array}$ & SYFPETHI & & $\begin{array}{l}100 \mu \mathrm{g} \text { emulsified in } \\
1: 1 \text { dilution with IFA; } \\
\text { SC }\end{array}$ & $\begin{array}{l}\text { FVB/N-DR1 } \\
\text { transgenic mice }\end{array}$ & $\begin{array}{l}\text { High levels of Th1-type } \\
\text { immune response and } \\
\text { significant level of IFN- } \gamma\end{array}$ & Rezvan (120) \\
\hline & $\begin{array}{l}\text { L. mexicana/ } \\
\text { L. major }\end{array}$ & $\begin{array}{l}\text { HLA-A2 peptides ( } 9 \\
\text { residues) }\end{array}$ & SYFPETHI & & $\begin{array}{l}100 \mu \mathrm{g}+140 \mu \mathrm{g} \\
\text { HAP-B (helper } \\
\text { peptide) }+50 \mu \mathrm{I} \text { IFA; } \\
\text { SC }\end{array}$ & $\begin{array}{l}\mathrm{HHDII} \text { and BALB/c } \\
\text { mice }\end{array}$ & $\begin{array}{l}\text { Induction of CTL } \\
\text { responses } \\
\text { Up-regulation of IFN- } \gamma\end{array}$ & Rezvan et al. (121) \\
\hline & L. donovani & $\begin{array}{l}\text { P1-P4 (9-18 } \\
\text { residues) }\end{array}$ & EpiMatrix & & $\begin{array}{l}100 \mu \mathrm{g} \text { of each } \\
\text { peptide }\end{array}$ & Human PBMCs & $\begin{array}{l}\text { Moderate increase in } \\
\text { IFN- } \gamma\end{array}$ & Elfaki et al. (122) \\
\hline KMP-11 & L. donovani & $\begin{array}{l}84 \text { Overlapping } \\
\text { peptides (9 residues) }\end{array}$ & SYFPEITHI & L. donovani & $44 \mu \mathrm{g} / \mathrm{ml}$ (each) & $\begin{array}{l}\mathrm{CD}^{+} \text {T-cells from } \\
\text { human PBMCs }\end{array}$ & $\begin{array}{l}\text { Trigger interferon- } \gamma \\
\text { secretion by } \mathrm{CD}^{+} \\
\text {T-cells }\end{array}$ & Basu et al. (123) \\
\hline
\end{tabular}




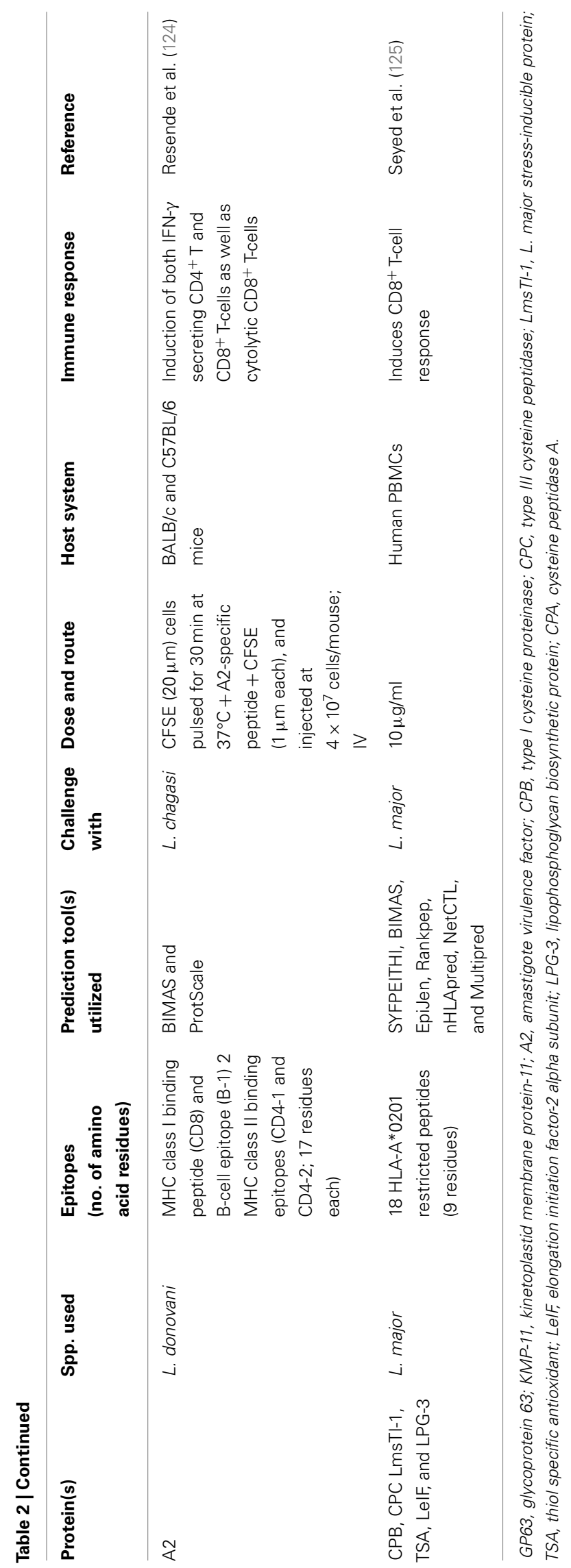

This zinc metalloprotease is expressed well both in promastigote as well as in amastigote form and implicated in a number of mechanisms related to parasite virulence. Also, proteinase activity of leishmanolysin results in increased resistance to complementmediated lysis. All these make it an attractive vaccine candidate. As early as in 1990, Jardim et al. (116) utilized primary structure of GP63 to delineate the structures of 7 T-cell epitopes (12-16 residues), which stimulate the proliferation of CD4+ cells. One of these synthetic antigens (with adjuvant) showed proliferation of the Thl subset when inoculated subcutaneously and provided immunoprotection against two species of Leishmania parasites. Eleven T-cell epitopes out of 24 partially overlapping peptides (12-35 residues) of GP63 of L. major have been identified and their prophylactic efficacy was assessed in CBA and BALB/c mice against $L$. major challenge. These epitopes induce a T-cell response suggesting GP63 as a dominant T-cell inducer in vivo. There is a clear segregation of the antigenicity and the immunogenicity of the peptides; only 3 of the 11 stimulatory peptides were able to induce a $\mathrm{T}$-cell response as well as being recognized by T-cells from recovered mice. Frankenburg et al. (118) also tested two peptides representing predicted T-cell epitopes of GP63 of L. major in vaccines tested in murine model of CL. Either subcutaneous (s.c.) or intraperitoneal (i.p.) immunization in saline with a peptide representing GP63 amino acids 467-482 (p467) significantly protected CBA mice against the development of severe cutaneous lesions only when the peptide was intrinsically adjuvanted by covalently adding a lauryl cysteine moiety (LC-p467) to its amino terminus during synthesis. A single synthetic T-cell epitope (PT3) was obtained from the histidine zinc-binding region of GP63 and was utilized in a vaccine trial using two virulent strains of $L$. major by Spitzer et al. (119). A single s.c. injection of PT3 with poloxamer 407 protected BALB/c mice for 10 months. Protection was similar for both strains, which manifest different disease sequelae. Elfaki et al. (122) used EpiMatrix algorithm to select putative T-cell epitopes of L. donovani GP63 in order to assess their immunogenicity in vitro. They found significant reduction in IL-10 level in all individual peptides as compared with unstimulated controls. Also, pooled peptides showed moderate increase in IFN- $\gamma$ level in some volunteers while individual peptides did not show significant difference from negative controls. Similarly, four HLA-A2 peptides of L. mexicana/major GP63 were predicted by SYFPETHI and tested in HHD II mice. Results revealed immunogenicity for three of four peptides predicted for HLA-A2 with induction of CTL responses detected by standard 4-h cytotoxicity assay and significant up-regulation of IFN- $\gamma$. When HHDII mice were injected i.m with L. mexicana GP63 cDNA and splenocytes were restimulated with blasts loaded with the immunogenic peptides, two of the peptides induced significant level of IFN- $\gamma$ detected by ELISA (121). Recently, three MHC class II - restricted peptides (AAR, AAP, and ASR) from L. major GP63 protein were predicted by SYFPEITHI and tested in FVB/N-DR1 transgenic mice. AAR produced high levels of Th1-type immune response as well as IFN- $\gamma(120)$.

\section{Kinetoplastid membrane protein-11}

An $11 \mathrm{kDa}$ highly conserved protein exclusively present in parasite cell membrane, differentially expressed more in amastigotes 
than in promastigotes, which further increases during metacyclogenesis, plays crucial role in host-parasite interaction (126). Basu et al. (123) scanned the entire sequence of KMP-11 of Leishmania with overlapping nonapeptides to decipher the role of CD8+ T-cells in defense against infection and in the cure of the disease. Thirty peptides that specifically trigger interferon- $\gamma$ secretion by human CD8+ T-cells were identified. Four T-cell lines with specificities for different peptides recognize Leishmania-infected autologous macrophages, which prove that KMP-11 is processed and presented via the MHC class I pathway of infected cells.

\section{A2 protein}

It is a member of amastigote stage-specific protein family, identified in L. donovani, required for the survival of amastigotes in visceral organs of mammalian host (127). It consists of multiple copies of a decameric amino acid repeat thus ranges from 45 to $100 \mathrm{kDa}$ inducing a strong Th1 immune response thus conferring partial protection against natural infection. Resende et al. (124) predicted hydrophilic, class I and II MHC-binding synthetic peptides recognized by $\mathrm{A} 2$-specific antibodies, $\mathrm{CD} 8+\mathrm{T}$ and $\mathrm{CD} 4+$ $\mathrm{T}$-cells, respectively. Immunization of $\mathrm{BALB} / \mathrm{c}$ mice with adenovirus expressing A2 (AdA2) resulted in low antibody response, contrasting with high levels of IFN- $\gamma$ producing CD4+ T and CD8+ T-cells specific for A2. Further, A2-specific CD8+ T-cells from immunized mice were capable of lysing sensitized target cells in vivo. They further demonstrated an association of A2-specific Tcell responses and reduced parasitism in both liver and spleen from mice immunized with AdA2 and challenged with L. (L.) chagasi. Six L. major antigens (CPB, CPC, LmsTI-1, TSA, LeIF, and LPG-3) were screened for potential CD8+ T-cell activating 9-mer epitopes presented by HLA-A ${ }^{\star} 0201$. Specific response to LmsTI-1 and LPG3 -related peptides presented in HLA-A*0201 was demonstrated (125). Recently, Agallou et al. (128) analyzed eight peptides from four known antigenic $L$. infantum proteins, i.e., cysteine peptidase A (CPA), histone H1, KMP-11, and Leishmania eukaryotic initiation factor (LeIF) for their immunogenicity in BALB/c mice where they found that CPA_p2, CPA_p3, LeIF_p3, and LeIF_p6 induced IFN- $\gamma$ producing CD4 + T-cells indicating a Th1-type response. In addition, CPA_p2, CPA_p3, and H1_p1 also induced CD8+ T-cells.

\section{CONCLUDING REMARKS}

For effective intervention measures to control VL in endemic areas, it is imperative to design a vaccine, which is the most economical way of controlling infectious diseases. An ideal vaccine involves suitable vaccine candidates, ought to offer long-lasting immunity, which is the prime pre-requisite for evaluating the efficacy of a vaccine. Although researchers utilize different approaches for designing vaccines against VL, they still face several challenges either due to heterogeneity of the human population or due to unusual host evasive mechanisms of parasite. The key step in vaccine designing is the identification of most appropriate vaccine candidate, which is found to be a time consuming and laborintensive task. Therefore, efforts were made for rationale and faster identification of potential antigens. With the emergence of immunoinformatics, peptide-based vaccines attract the most due its several merits. These vaccines should include promiscuous T-cell epitopes derived from the potential Th1 stimulatory proteins of L. donovani, which expands host protective immune responses.

\section{REFERENCES}

1. Chappuis F, Sundar S, Hailu A, Ghalib H, Rijal S, Peeling RW, et al. Visceral leishmaniasis: what are the needs for diagnosis, treatment and control? Nat Rev Microbiol (2007) 5:873-82. doi:10.1038/nrmicro1748

2. Hasker E, Singh SP, Malaviya P, Picado A, Gidwani K, Singh RP, et al. Visceral leishmaniasis in rural Bihar, India. Emerg Infect Dis (2012) 18(10):1662-4. doi:10.3201/eid1810.111083

3. Desjeux P. Leishmaniasis. Nat Rev Microbiol (2004) 2:692-3. doi:10.1038/ nrmicro981

4. Piscopo T, Azzopardi M. Leishmaniasis. Postgrad Med J (2006) 83:649-57. doi:10.1136/pgmj.2006.047340corr1

5. Lukes J, Mauricio IL, Schonian G, Dujardin JC, Soteriadou K, Dedet JP, et al. Evolutionary and geographical history of the Leishmania donovani complex with a revision of current taxonomy. Proc Natl Acad Sci U S A (2007) 104:9375-80. doi:10.1073/pnas.0703678104

6. Lodge R, Diallo TO, Descoteaux A. Leishmania donovani lipophosphoglycan blocks NADPH oxidase assembly at the phagosome membrane. Cell Microbiol (2006) 8:1922-31. doi:10.1111/j.1462-5822.2006.00758.x

7. Kedzierski L. Leishmaniasis vaccine: where are we today? J Glob Infect Dis (2010) 2(2):177-85. doi:10.4103/0974-777X.62881

8. Croft SL, Sundar S, Fairlamb AH. Drug resistance in leishmaniasis. Clin Microbiol Rev (2006) 19:111-26. doi:10.1128/CMR.19.1.111-126.2006

9. Mutiso JM, Macharia JC, Kiio MN, Ichagichu JM, Rikoi H, Gicheru MM. Development of Leishmania vaccines: predicting the future from past and present experience. J Biomed Res (2013) 27(2):85-102. doi:10.7555/JBR.27.20120064

10. Kamhawi S, Oliveira F, Valenzuela JG. Using humans to make a human leishmaniasis vaccine. Sci Transl Med (2014) 6:234fs18. doi:10.1126/scitranslmed. 3009118

11. Kharazmi A, Kemp K, Ismail A, Gasim S, Gaafar A, Kurtzhals JA, et al. T-cell response in human leishmaniasis. Immunol Lett (1999) 65:105-8. doi:10.1016/S0165-2478(98)00132-1

12. Stager S, Smith DF, Kaye PM. Immunization with a recombinant stageregulated surface protein from Leishmania donovani induces protection against visceral leishmaniasis. J Immunol (2000) 165:7064-71. doi:10.4049/jimmunol. 165.12.7064

13. Kumari S, Kumar A, Samant M, Sundar S, Singh N, Dube A. Proteomic approaches for discovery of new targets for vaccine and therapeutics against visceral leishmaniasis. Proteomics Clin Appl (2008) 3:372-86. doi:10.1002/prca. 200780017

14. Lundegaard C, Lund O, Kesmir C, Brunak S, Nielsen M. Modeling the adaptive immune system: predictions and simulations. Bioinformatics (2007) 23(24):3265-75. doi:10.1093/bioinformatics/btm471

15. Palatnik de Sousa CB. Vaccines for leishmaniasis in the fore coming 25 years. Vaccine (2008) 26:1709-24. doi:10.1016/j.vaccine.2008.01.023

16. Bray RS, Modabber F. The history of leishmaniasis. In: Gilles HM, editor. Protozoal Diseases. New York, NY: Hodder Arnold Publisher (2000). p. 414-9.

17. Handman E. Leishmaniasis: current status of vaccine development. Clin Microbiol Rev (2001) 14:229-43. doi:10.1128/CMR.14.2.229-243.2001

18. Pessoa SB. Segunda nota sobre a vacinacao preventiva na leishmaniose tegumentar Americana com leptomones mortas. Rev Paul Med (1941) 19:106.

19. Pessoa SB, Pestana BR. Enseaio sobre vacinacao preventive na leishmaniose tegumentar americana com germenes mortos. Arq Hig Saude Publ (1941) 6:141-7.

20. Basyoni MM. Leishmania vaccines updates. PUJ (2012) 5(1):1-10.

21. Zijlstra EE, El-Hassan AM, Ismael A, Ghalib HW. Endemic kala-azar in eastern Sudan: a longitudinal study on the incidence of clinical and subclinical infection and post-kala-azar dermal leishmaniasis. Am J Trop Med Hyg (1994) 51:826-36.

22. Dube A, Sharma P, Srivastava JK, Misra A, Naik S, Katiyar JC. Vaccination of langur monkeys (Presbytis entellus) against Leishmania donovani with autoclaved L. major plus BCG. Parasitology (1998) 116:219-21. doi:10.1017/ S0031182097002175 
23. Misra A, Dube A, Srivastava B, Sharma P, Srivastava JK, Katiyar JC, et al. Successful vaccination against Leishmania donovani infection in Indian langur using alum-precipitated autoclaved Leishmania major with BCG. Vaccine (2001) 19:3485-92. doi:10.1016/S0264-410X(01)00058-5

24. Khalil EA, El-Hassan AM, Zijlstra EE, Mukhtar MM, Ghalib HW, Musa B, et al. Autoclaved Leishmania major vaccine for prevention of visceral leishmainiasis: a randomised, double-blind, BCG-controlled trial in Sudan. Lancet (2000) 356:1565-9. doi:10.1016/S0140-6736(00)03128-7

25. Kamil AA, Khalil EA, Musa AM, Modabber F, Mukhtar MM, Ibrahim $\mathrm{ME}$, et al. Alum-precipitated autoclaved Leishmania major plus Bacillus Calmette-Guerrin, a candidate vaccine for visceral leishmaniasis: safety, skindelayed type hypersensitivity response and dose finding in healthy volunteers. Trans R Soc Trop Med Hyg (2003) 97(3):365-8. doi:10.1016/S0035-9203(03) 90171-4

26. Mohebali M, Khamesipour A, Mobedi I, Zarei Z, Hashemi-Fesharki R. Double blind randomized efficacy field trial of alum precipitated autoclaved Leishmania major vaccine mixed with BCG against canine visceral leishmaniasis in Meshkin-Shahr district, I. R. Iran. Vaccine (2004) 22:4097-100. doi:10.1016/j.vaccine.2004.03.058

27. Musa AM, Khalil EA, Mahgoub FA, Elgawi SH, Modabber F, Elkadaru AE, et al. Immunochemotherapy of persistent post-kala-azar dermal leishmaniasis: a novel approach to treatment. Trans R Soc Trop Med Hyg (2008) 102:58-63. doi:10.1016/j.trstmh.2007.08.006

28. De Luca PM, Mayrink W, Alves CR, Coutinho SG, Oliveira MP, Bertho AL, et al. Evaluation of the stability and immunogenicity of autoclaved and nonautoclaved preparations of a vaccine against American tegumentary leishmaniasis. Vaccine (1999) 17:1179-85. doi:10.1016/S0264-410X(98)00338-7

29. Breton M, Tremblay MJ, Ouellette M, Papadopoulou B. Live nonpathogenic parasitic vector as a candidate vaccine against visceral leishmaniasis. Infect Immun (2005) 73:6372-82. doi:10.1128/IAI.73.10.6372-6382.2005

30. Papadopoulou B, Roy G, Breton M, Kundig C, Dumas C, Fillion I, et al. Reduced Infectivity of a Leishmania donovani biopterin transporter genetic mutant and its use as an attenuated strain for vaccination. Infect Immun (2002) 70:62-8. doi:10.1128/IAI.70.1.62-68.2002

31. Silvestre R, Cordeiro-da-Silva A, Santarém N, Vergnes B, Sereno D, Ouaissi A. SIR2-deficient Leishmania infantum induces a defined IFN- $\gamma /$ IL-10 pattern that correlates with protection. J Immunol (2007) 179:3161-70. doi:10.4049/ jimmunol.179.5.3161

32. Mizbani A, Taheri T, Zahedifard F, Taslimi Y, Azizi H, Azadmanesh K, et al. Recombinant Leishmania tarentolae expressing the A2 virulence gene as a novel candidate vaccine against visceral leishmaniasis. Vaccine (2009) 28:53-62. doi:10.1016/j.vaccine.2009.09.114

33. Dey R, Dagur PK, Selvapandiyan A, McCoy JP, Salotra P, Duncan R, et al. Live attenuated Leishmania donovani p27 gene knockout parasites are nonpathogenic and elicit long-term protective immunity in BALB/c mice. J Immunol (2013) 190(5):2138-49. doi:10.4049/jimmunol.1202801

34. Kumari S, Samant M, Khare P, Misra P, Dutta S, Kolli BK, et al. Photodynamic vaccination of hamsters with inducible suicidal mutants of Leishmania amazonensis elicits immunity against visceral leishmaniasis. Eur J Immunol (2009) 39:178-91. doi:10.1002/eji.200838389

35. Selvapandiyan A, Dey R, Nylen R, Duncan R, Sacks D, Nakasi HL. Intracellular replication-deficient Leishmania donovani induces long lasting protective immunity against visceral leishmaniasis. J Immunol (2009) 183:1813-20. doi:10.4049/jimmunol.0900276

36. Fiuza JA, Santiago HC, Selvapandiyan A, Gannavaram S, Ricci ND, Bueno LL, et al. Induction of immunogenicity by live attenuated Leishmania donovani centrin deleted parasites in dogs. Vaccine (2013) 31:1785-92. doi:10.1016/j. vaccine.2013.01.048

37. Mutiso JM, Macharia JC, Taracha E, Gicheru MM. Leishmania donovani whole cell antigen delivered with adjuvants protects against visceral leishmaniasis in vervet monkeys (Chlorocebus aethiops). J Biomed Res (2012) 26:8-16. doi:10.1016/S1674-8301(12)60002-5

38. Jaffe CL, Rachamim N, Sarfstein R. Characterization of two proteins from Leishmania donovani and their use for vaccination against visceral leishmaniasis. J Immunol (1990) 144:699-706.

39. Palatnik de Sousa CB, Paraguai de Souza E, Gomes EM, Borojevic R. Experimental murine Leishmania donovani infection: immunoprotection by the fucose-mannose ligand (FML). Braz J Med Biol Res (1994) 27:547-55.
40. Palatnik de Sousa CB, Moreno MB, Paraguai de Souza E, Borojevic R. The FML-vaccine (fucose-mannose ligand) protects hamsters from experimental kala-azar. J Braz Assoc Adv Sci (1994) 46:290-6.

41. Santos WR, Paraguai de Souza E, Palatnik M, Palatnik de Sousa CB. Vaccination of Swiss albino mice against experimental visceral leishmaniasis with the FML antigen of Leishmania donovani. Vaccine (1999) 17:2554-61. doi:10.1016/S0264-410X(99)00058-4

42. Saraiva EM, de Figueiredo Barbosa A, Santos FN, Borja-Cabrera GP, Nico D, Souza LO, et al. The FML-vaccine (Leishmune) against canine visceral leishmaniasis: a transmission blocking vaccine. Vaccine (2006) 24:2423-31. doi:10.1016/j.vaccine.2005.11.061

43. Lemesre JL, Holzmuller P, Cavaleyra M, Goncalves RB, Hottin G, Papierok G. Protection against experimental visceral leishmaniasis infection in dogs immunized with purified excreted secreted antigens of Leishmania infantum promastigotes. Vaccine (2005) 23:2825-40. doi:10.1016/j.vaccine.2004.11.061

44. Bourdoiseau G, Hugnet C, Goncalves RB. Effective humoral and cellular immunoprotective responses in LiESAp-MDP vaccinated protected dogs. Vet Immunol Immunopathol (2009) 128:71-8. doi:10.1016/j.vetimm.2008.10.309

45. Wilson ME, Young BM, Andersen KP, Weinstock JV, Metwali A, Ali KM, et al. A recombinant Leishmania chagasi antigen that stimulates cellular immune responses in infected mice. Infect Immun (1995) 63:2062-9.

46. Fernandes AP, Costa MM, Coelho EA, Michalick MS, de Freitas E, Melo MN, et al. Protective immunity against challenge with Leishmania chagasi in beagle dogs vaccinated with recombinant A2 protein. Vaccine (2008) 26:5888-95. doi:10.1016/j.vaccine.2008.05.095

47. Bhardwaj S, Vasishta RK, Arora SK. Vaccination with a novel recombinant Leishmania antigen plus MPL provides partial protection against L. donovani challenge in experimental model of visceral leishmaniasis. Exp Parasitol (2009) 121:29-37. doi:10.1016/j.exppara.2008.09.019

48. Kushawaha PK, Gupta R, Sundar S, Sahasrabuddhe AA, Dube A. Elongation factor-2, a Th1 stimulatory protein of Leishmania donovani, generates strong IFN- $\gamma$ and IL-12 response in cured Leishmania-infected patients/hamsters and protects hamsters against Leishmania challenge. J Immunol (2011) 187:6417-27. doi:10.4049/jimmunol.1102081

49. Gupta R, Kushawaha PK, Tripathi CD, Sundar S, Dube A. A novel recombinant Leishmania donovani $\mathrm{p} 45$, a partial coding region of methionine aminopeptidase, generates protective immunity by inducing a Thl stimulatory response against experimental visceral leishmaniasis. Int J Parasitol (2012) 42(5):429-35. doi:10.1016/j.ijpara.2012.02.013

50. Kushawaha PK, Gupta R, Tripathi CD, Khare P, Jaiswal AK, Sundar S, et al. Leishmania donovani triose phosphate isomerase: a potential vaccine target against visceral leishmaniasis. PLoS One (2012) 7:e45766. doi:10.1371/journal. pone.0045766

51. Kushawaha PK, Gupta R, Tripathi CD, Sundar S, Dube A. Evaluation of Leishmania donovani protein disulfide isomerase as a potential immunogenic protein/vaccine candidate against visceral leishmaniasis. PLoS One (2012) 7:e35670. doi:10.1371/journal.pone.0035670

52. Khare P, Jaiswal AK, Tripathi CD, Joshi S, Sundar S, Dube A. Efficacy of Leishmania donovani trypanothione reductase, identified as a potent Th1 stimulatory protein, for its immunogenicity and prophylactic potential against experimental visceral leishmaniasis. Parasitol Res (2014) 113:851-62. doi:10.1007/ s00436-013-3716-5

53. Gupta R, Kumar V, Kushawaha PK, Tripathi CP, Joshi S, Sahasrabuddhe AA, et al. Characterization of glycolytic enzymes - rAldolase and rEnolase of Leishmania donovani, identified as Th1 stimulatory proteins, for their immunogenicity and immunoprophylactic efficacies against experimental visceral leishmaniasis. PLoS One (2014) 9(1):e86073. doi:10.1371/journal.pone. 0086073

54. Chavez-Fumagalli MA, Costa MA, Oliveira DM, Ramirez L, Costa LE, Duarte $\mathrm{MC}$, et al. Vaccination with the Leishmania infantum ribosomal proteins induces protection in BALB/c mice against Leishmania chagasi and Leishmania amazonensis challenge. Microbes Infect (2010) 12:967-77. doi:10.1016/j.micinf. 2010.06.008

55. Martins VT, Chavez-Fumagalli MA, Costa LE, Canavac AM, Lage PS, Duarte $\mathrm{MC}$, et al. Antigenicity and protective efficacy of a Leishmania amastigote specific protein, member of the super-oxygenase family, against visceral leishmaniasis. PLoS Negl Trop Dis (2013) 7(3):e2148. doi:10.1371/journal.pntd. 0002148 
56. Choudhury R, Das P, Bhaumik SK, De T, Chakraborti T. In situ immunolocalization and stage-dependent expression of a secretory serine protease in Leishmania donovani and its role as a vaccine candidate. Clin Vaccine Immunol (2010) 17:660-7. doi:10.1128/CVI.00358-09

57. Lemesre JL, Holzmuller P, Goncalves RB, Bourdoiseau G, Hugnet C, Cavaleyra $\mathrm{M}$, et al. Long-lasting protection against canine visceral leishmaniasis using the LiESAp-MDP vaccine in endemic areas of France: doubleblind randomised efficacy field trial. Vaccine (2007) 25:4223-34. doi:10.1016/ j.vaccine.2007.02.083

58. Molano I, Garcia Alonso M, Miron C. A Leishmania infantum multicomponent antigenic protein mixed with live BCG confers protection to dogs experimentally infected with L. infantum. Vet Immunol Immunopathol (2003) 92:1-13. doi:10.1016/S0165-2427(02)00315-X

59. Parody N, Soto M, Requena JM, Lonso CA. Adjuvant guided polarization of the immune humoral response against a protective multicomponent antigenic protein (Q) from Leishmania infantum. A CpG $+\mathrm{Q}$ mix protects Balb/c mice from infection. Parasite Immunol (2004) 26:283-93. doi:10.1111/j.0141-9838. 2004.00711.x

60. Gradoni L, Foglia Manzillo V, Pagano A, Piantedosi D, De Luna R, Gramiccia $\mathrm{M}$, et al. Failure of a multi-subunit recombinant Leishmania vaccine (MML) to protect dogs from Leishmania infantum infection and to prevent disease progression in infected animals. Vaccine (2005) 23:5245-51. doi:10.1016/j.vaccine.2005.07.001

61. Coler RN, Yasuyuki G, Bogatzki L, Raman V, Reed SG. Leish-111f, a recombinant polyprotein vaccine that protects against visceral leishmaniasis by elicitation of CD4+ T cells. Infect Immun (2007) 75:4648-54. doi:10.1128/IAI. 00394-07

62. Trigo J, Abbehusen M, Netto EM, Nakatani M, Pedral-Sampaio G, de Jesus RS. Treatment of canine visceral leishmaniasis by the vaccine Leish-111f +MPL-SE. Vaccine (2010) 28:3333-40. doi:10.1016/j.vaccine.2010.02.089

63. Bertholet S, Goto Y, Carter L. Optimized subunit vaccine protects against experimental leishmaniasis. Vaccine (2009) 23:7036-45. doi:10.1016/j.vaccine.2009. 09.066

64. Goto Y, Bhatia A, Raman VS, Liang H, Mohamath R, Picone AF, et al. KSAC, the first defined polyprotein vaccine candidate for visceral leishmaniasis. Clin Vaccine Immunol (2011) 18:1118-24. doi:10.1128/CVI.05024-11

65. Ghosh A, Zhang WW, Matlashewski G. Immunization with A2 protein results in a mixed Th1/Th2 and a humoral response which protects mice against Leishmania donovani infections. Vaccine (2001) 20:59-66. doi:10.1016/S0264$410 \mathrm{X}(01) 00322-\mathrm{X}$

66. Melby PC, Yang J, Zhao W, Perez LE, Cheng J. Leishmania donovani p36 (LACK) DNA vaccine is highly immunogenic but not protective against experimental visceral leishmaniasis. Infect Immun (2001) 69:4719-25. doi:10.1128/IAI.69.8. 4719-4725.2001

67. Sukumaran B, Tewary P, Saxena S, Madhubala R. Vaccination with DNA encoding ORFF antigen confers protective immunity in mice infected with Leishmania donovani. Vaccine (2003) 21:1292-9. doi:10.1016/S0264-410X(02)00352-3

68. Basu R, Bhaumik S, Basu JM, Naskar K, De T, Roy S. Kinetoplastid membrane protein-11 DNA vaccination induces complete protection against both pentavalent antimonial sensitive and resistant strains of Leishmania donovani that correlates with inducible nitric oxide synthase activity and IL-4 generation: evidence for mixed Th1- and Th2-like responses in visceral leishmaniasis. J Immunol (2005) 174:7160-71. doi:10.4049/jimmunol.174.11.7160

69. Bhaumik S, Basu R, Sen S, Naskar K, Roy S. KMP-11 DNA immunization significantly protects against $L$. donovani infection but requires exogenous IL12 as an adjuvant for comparable protection against L. major. Vaccine (2009) 27:1306-16. doi:10.1016/j.vaccine.2008.12.053

70. Saldarriaga OA, Travi BL, Park W, Perez LE, Melby PC. Immunogenicity of a multicomponent DNA vaccine against visceral leishmaniasis in dogs. Vaccine (2006) 24:1928-40. doi:10.1016/j.vaccine.2005.10.052

71. Carter KC, Henriquez FL, Campbell SA, Roberts CW, Nok A, Mullen AB, et al. DNA vaccination against the parasite enzyme gamma glutamyl cysteine synthetase confers protection against Leishmania donovani infection. Vaccine (2007) 25:4502-9. doi:10.1016/j.vaccine.2007.03.014

72. Sharma A, Madhubala R. Ubiquitin conjugation of open reading frame F DNA vaccine leads to enhanced cell-mediated immune response and induces protection against both antimony-susceptible and -resistant strains of Leishmania donovani. J Immunol (2009) 183:7719-31. doi:10.4049/jimmunol.0900132
73. Samant M, Gupta R, Kumari S, Misra P, Khare P, Kushawaha PK, et al. Immunization with the DNA-encoding N-terminal domain of proteophosphoglycan of Leishmania donovani generates Th1-type immunoprotective response against experimental visceral leishmaniasis. J Immunol (2009) 183:470-9. doi:10.4049/jimmunol.0900265

74. Guha R, Gupta D, Rastogi R, Vikram R, Krishnmurthy G, Bimal S, et al. Vaccination with Leishmania hemoglobin receptor-encoding DNA protects against visceral leishmaniasis. Sci Transl Med (2013) 5(202):202ra121. doi:10.1126/ scitranslmed.3006406

75. Marques-da-Silva EA, Coelho EA, Gomes DC, Vilela MC, Masioli CZ, Tavares $\mathrm{CA}$, et al. Intramuscular immunization with p36(LACK) DNA vaccine induces IFN- $\gamma$ production but does not protect BALB/c mice against Leishmania chagasi intravenous challenge. Parasitol Res (2005) 98(1):67-74. doi:10.1007/s00436005-0008-8

76. Fragaki K, Suffia I, Ferrua B, Rousseau D, Le Fichoux Y, Kubar J. Immunisation with DNA encoding Leishmania infantum protein papLe22 decreases the frequency of parasitemic episodes in infected hamsters. Vaccine (2001) 19:1701-9. doi:10.1016/S0264-410X(00)00398-4

77. Gomes DC, Pinto EF, de Melo LD, Lima WP, Larraga V, Lopes UG, et al. Intranasal delivery of naked DNA encoding the LACK antigen leads to protective immunity against visceral leishmaniasis in mice. Vaccine (2007) 25(12):2168-72. doi:10.1016/j.vaccine.2006.11.060

78. Carrion J, Folgueira C, Alonso C. Immunization strategies against visceral leishmaniasis with the nucleosomal histones of Leishmania infantum encoded in DNA vaccine or pulsed in dendritic cells. Vaccine (2008) 26:2537-44. doi:10.1016/j.vaccine.2008.03.003

79. Aguilar-Be I, da Silva Zardo R, Paraguai de Souza E, Borja-Cabrera GP, RosadoVallado M, Mut-Martin M, et al. Cross-protective efficacy of a prophylactic Leishmania donovani DNA vaccine against visceral and cutaneous murine leishmaniasis. Infect Immun (2005) 73(2):812-9. doi:10.1128/IAI.73.2.812819.2005

80. Gamboa-Leon R, Paraguaide Souza E, Borja-Cabrera GP, Santos FN, Myashiro LM, Pinheiro RO, et al. Immunotherapy against visceral leishmaniasis with the nucleoside hydrolase DNA vaccine of Leishmania donovani. Vaccine (2006) 24:4863-73. doi:10.1016/j.vaccine.2006.03.005

81. Zanin FH, Coelho EA, Tavares CA, Marques-da-Silva EA, Costa MM, Rezende $\mathrm{SA}$, et al. Evaluation of immune responses and protection induced by $\mathrm{A} 2$ and nucleoside hydrolase (NH) DNA vaccines against Leishmania chagasi and Leishmania amazonensis experimental infections. Microbes Infect (2007) 9:1070-7. doi:10.1016/j.micinf.2007.05.012

82. Tewary P, Jain M, Sahani MH, Saxena S, Madhubala R. A heterologous primeboost vaccination regimen using ORFF DNA and recombinant ORFF protein confers protective immunity against experimental visceral leishmaniasis. J Infect Dis (2005) 191:2130-7. doi:10.1086/430348

83. Mazumder S, Maji M, Das A, Ali N. Potency, efficacy and durability of DNA/DNA, DNA/protein and protein/protein based vaccination using GP63 against Leishmania donovani in BALB/c mice. PLoS One (2011) 6:e14644. doi:10.1371/journal.pone.0014644

84. Dondji B, Perez-Jimenez E, Goldsmith-Pestana K, Esteban M, McMahonPratt D. Heterologous prime - boost vaccination with the LACK antigen protects against murine visceral leishmaniasis. Infect Immun (2005) 73:5286-9. doi:10.1128/IAI.73.8.5286-5289.2005

85. Ramiro MJ, Zarate JJ, Hanke T, Rodriguez D, Rodriguez JR, Esteban M, et al. Protection in dogs against visceral leishmaniasis caused by Leishmania infantum is achieved by immunization with a heterologous prime-boost regime using DNA vaccine and vaccinia recombinant vectors expressing LACK. Vaccine (2003) 21:2474-84. doi:10.1016/S0264-410X(03)00032-X

86. Rafati S, Zahedifard F, Nazgouee F. Prime boost vaccination using cysteine proteinases type I and II of Leishmania infantum confers protective immunity in murine visceral leishmaniasis. Vaccine (2006) 24:2169-75. doi:10.1016/ j.vaccine.2005.11.011

87. Rafati S, Nakhaee A, Taheri T, Taslimi Y, Darabi H, Eravani D, et al. Protective vaccination against experimental canine visceral leishmaniasis using a combination of DNA and protein immunization with cysteine proteinases type I and II of L. infantum. Vaccine (2005) 23(28):3716-25. doi:10.1016/j.vaccine.2005. 02.009

88. Afrin F, Rajesh R, Anam K, Gopinath M, Pal S, Ali N. Characterization of Leishmania donovani antigens encapsulated in liposomes that induce 
protective immunity in BALB/c mice. Infect Immun (2002) 70:6697-706. doi:10.1128/IAI.70.12.6697-6706.2002

89. Mazumder S, Ravindran R, Banerjee A, Ali N. Non-coding pDNA bearing immunostimulatory sequences co-entrapped with Leishmania antigens in cationic liposomes elicits almost complete protection against experimental visceral leishmaniasis in BALB/c mice. Vaccine (2007) 25:8771-81. doi:10.1016/j.vaccine.2007.10.028

90. Bhowmick S, Ravindran R, Ali N. GP63 in stable cationic liposomes confers sustained vaccine immunity to susceptible BALB/c mice infected with Leishmania donovani. Infect Immun (2008) 76:1003-15. doi:10.1128/IAI.00611-07

91. Agallou M, Smirlis D, Soteriadou KP, Karagouni E. Vaccination with Leishmania histone H1-pulsed dendritic cells confers protection in murine visceral leishmaniasis. Vaccine (2012) 30:5086-93. doi:10.1016/j.vaccine.2012.05.075

92. Gomes R, Teixeira C, Teixeira MJ, Oliveira F, Menezes MJ, Silva C, et al. Immunity to a salivary protein of a sandfly vector protects against the fatal outcome of visceral leishmaniasis in a hamster model. Proc Natl Acad Sci U S A (2008) 105:7845-50. doi:10.1073/pnas.0712153105

93. Collin N, Gomes R, Teixeira C, Cheng L, Laughinghouse A, Ward JM, et al. Sand fly salivary proteins induce strong cellular immunity in a natural reservoir of visceral leishmaniasis with adverse consequences for Leishmania. PLoS Pathog (2009) 5(5):e1000441. doi:10.1371/journal.ppat.1000441

94. Reis AB, Giunchetti RC, Carrillo E, Martins-Filho OA, Moreno J. Immunity to Leishmania and the rational search for vaccines against canine leishmaniasis. Trends Parasitol (2010) 26(7):341-9. doi:10.1016/j.pt.2010.04.005

95. Coler RN, Reed SG. Second-generation vaccines against leishmaniasis. Trends Parasitol (2005) 21:244-9. doi:10.1016/j.pt.2005.03.006

96. Campos-Neto A, Porrozzi R, Greeson K, Coler RN, Webb JR, Seiky YA, et al. Protection against cutaneous leishmaniasis induced by recombinant antigens in murine and nonhuman primate models of the human disease. Infect Immun (2001) 69:4103-8. doi:10.1128/IAI.69.6.4103-4108.2001

97. Noazin S, Modabber F, Khamesipour A, Smith PG, Moulton LH, Nasseri K, et al. First generation leishmaniasis vaccines: a review of field efficacy trials. Vaccine (2008) 26:6759-67. doi:10.1016/j.vaccine.2008.09.085

98. Kaye P, Scott P. Leishmaniasis: complexity at the host pathogen interface. Nat Rev Microbiol (2011) 9:604-15. doi:10.1038/nrmicro2608

99. Kumar R, Engwerda C. Vaccines to prevent leishmaniasis. Clin Trans Immunol (2014) 3:e13. doi:10.1038/cti.2014.4

100. Kumari S, Samant M, Khare P, Sundar S, Sinha S, Dube A. Induction of Th1type cellular responses in cured/exposed Leishmania-infected patients and hamsters against polyproteins of soluble Leishmania donovani promastigotes ranging from 89.9 to $97.1 \mathrm{kDa}$. Vaccine (2008) 26:4813-8. doi:10.1016/j.vaccine. 2008.06.102

101. Kumari S, Samant M, Misra P, Khare P, Sisodia B, Shasany AK, et al. Th1stimulatory polyproteins of soluble Leishmania donovani promastigotes ranging from 89.9 to $97.1 \mathrm{kDa}$ offers long-lasting protection against experimental visceral leishmaniasis. Vaccine (2008) 26:5700-11. doi:10.1016/j.vaccine.2008. 08.021

102. Vedvick TS, Carter L, Garner M, Goto Y, Bertholet S, Reed SG, et al. An improved manufacturing process for a recombinant polyprotein vaccine. Biopharm Inter (2008) January(Supplement):14-22.

103. Das S, Freier A, Boussoffara T, Das S, Oswald D, Losch FO, et al. Modular multiantigen $\mathrm{T}$ cell epitope-enriched DNA vaccine against human leishmaniasis. Sci Transl Med (2014) 6:234ra56. doi:10.1126/scitranslmed.3008222

104. Bhowmick S, Mazumdar T, Sinha R, Ali N. Comparison of liposome based antigen delivery systems for protection against Leishmania donovani. J Control Release (2010) 141:199-207. doi:10.1016/j.jconrel.2009.09.018

105. Valenzuela JG, Belkaid Y, Garfield MK, Mendez S, Kamhawi S, Rowton ED, et al. Toward a defined anti-Leishmania vaccine targeting vector antigens: characterization of a protective salivary protein. J Exp Med (2001) 194(3):331-42. doi:10.1084/jem.194.3.331

106. Morris RV, Shoemaker CB, David JR, Lanzaro GC, Titus RG. Sandfly maxadilan exacerbates infection with Leishmania major and vaccinating against it protects against L. major infection. J Immunol (2001) 167:5226-30. doi:10. 4049/jimmunol.167.9.5226

107. Duthie MS, Reed SG. The emergence of defined subunit vaccines for the prevention of leishmaniasis. Curr Trop Med Rep (2014) 1(3):154-62. doi:10.1007/ s40475-014-0024-9
108. Silvestre R, Cordeiro-da-Silva A, Ouaissi A. Live attenuated Leishmania vaccines: a potential strategic alternative. Arch Immunol Ther Exp (Warsz) (2008) 56(2):123-6. doi:10.1007/s00005-008-0010-9

109. Sporri R, Reis e Sousa C. Inflammatory mediators are insufficient for full dendritic cell activation and promote expansion of CD4+ T cell populations lacking helper function. Nat Immunol (2005) 6:163-70. doi:10.1038/ni1 162

110. Foulds KE, Wu CY, Seder RA. Th1 memory: implications for vaccine development. Immunol Rev (2006) 211:58-66. doi:10.1111/j.0105-2896.2006. 00400.x

111. Titus RG, Gueiros-Filho FJ, De Freitas LA, Beverley SM. Development of a safe live Leishmania vaccine line by gene replacement. Proc Natl Acad Sci U S A (1995) 92(22):10267-71. doi:10.1073/pnas.92.22.10267

112. Selvapandiyan A, Debrabant A, Duncan R. Centrin gene disruption impairs stage-specific basal body duplication and cell cycle progression in Leishmania. J Bio Chem (2004) 279(24):25703-10. doi:10.1074/jbc.M402794200

113. Nardin E. The past decade in malaria synthetic peptide vaccine clinical trials. Hum Vaccin (2010) 6(1):27-38. doi:10.4161/hv.6.1.9601

114. Wang Y, Wang G, Zhang D, Yin H, Wang M. Screening and identification of novel B cell epitopes of Toxoplasma gondii SAG1. Parasit Vectors (2013) 6:125. doi:10.1186/1756-3305-6-125

115. Serna C, Lara JA, Rodrigues SP, Marques AF, Almeida IC, Maldonado RA. A synthetic peptide from Trypanosoma cruzi mucin-like associated surface protein as candidate for a vaccine against Chagas disease. Vaccine (2014) 32:3525-32. doi:10.1016/j.vaccine.2014.04.026

116. Jardim A, Alexander J, Teh HS, Ou D, Olafson RW. Immunoprotective Leishmania major synthetic T-cell epitopes. J Exp Med (1990) 172:645-8. doi:10.1084/jem.172.2.645

117. Yang DM, Rogers MV, Liew FY. Identification and characterization of hostprotective T-cell epitopes of a major surface glycoprotein (GP63) from Leishmania major. J Immunol (1991) 72:3-9.

118. Frankenburg S, Axelrod O, Kutner S, Greenblatt CL, Klaus SN, Pirak EA, et al. Effective immunization of mice against cutaneous leishmaniasis using an intrinsically adjuvanted synthetic lipopeptide vaccine. Vaccine (1996) 14(9):923-9. doi:10.1016/0264-410X(95)00245-V

119. Spitzer N, Jardim A, Lippert D, Olafson RW. Long-term protection of mice against Leishmania major with a synthetic peptide vaccine. Vaccine (1999) 17:1298-300. doi:10.1016/S0264-410X(98)00363-6

120. Rezvan H. Immunogenicity of HLA-DR1 restricted peptides derived from Leishmania major GP63 using FVB/N-DR1 transgenic mouse model. Iran J Parasitol (2013) 8(2):273-9.

121. Rezvan H, Rees R, Ali SA. Immunogenicity of MHC class I peptides derived from Leishmania mexicana GP63 in HLA-A2.1 transgenic (HHDII) and BALB/C mouse models. Iran J Parasitol (2012) 7(4):27-40.

122. Elfaki ME, Khalil EA, Groot AS, Musa AM, Gutierrez A, Younis BM, et al. Immunogenicity and immune modulatory effects of in silico predicted L. donovani candidate peptide vaccines. Hum Vaccin Immunother (2012) 8(12):1769-74. doi:10.4161/hv.21881

123. Basu R, Roy S, Walden P. HLA class I-restricted T cell epitopes of the kinetoplastid membrane protein-11 presented by Leishmania donovani-infected human macrophages. J Infect Dis (2007) 195:1373-80. doi:10.1086/513439

124. Resende DM, Caetano BC, Dutra MS, Penido ML, Abrantes CF, Verly RM, et al. Epitope mapping and protective immunity elicited by adenovirus expressing the Leishmania amastigote specific A2 antigen: correlation with IFN- $\gamma$ and cytolytic activity by CD8+ T cells. Vaccine (2008) 26:4585-93. doi:10.1016/j. vaccine.2008.05.091

125. Seyed N, Zahedifard F, Safaiyan S, Gholami E, Doustdari F, Azadmanesh K, et al. In silico analysis of six known Leishmania major antigens and in vitro evaluation of specific epitopes eliciting HLA-A2 restricted CD8 T cell response. PLoS Negl Trop Dis (2011) 5(9):e1295. doi:10.1371/journal.pntd.0001295

126. Matos DC, Faccioli LA, Cysne-Finkelstein L, Luca PM, Corte-Real S, Armoa $\mathrm{GR}$, et al. Kinetoplastid membrane protein-11 is present in promastigotes and amastigotes of Leishmania amazonensis and its surface expression increases during metacyclogenesis. Mem Inst Oswaldo Cruz (2010) 105:341-7. doi:10. 1590/S0074-02762010000300018

127. Charest H, Matlashewski G. Developmental gene expression in Leishmania donovani: differential cloning and analysis of an amastigote-stage-specific gene. Mol Cell Biol (1994) 14:2975-84. 
128. Agallou M, Athanasiou E, Koutsoni O, Dotsika E, Karagouni E. Experimental validation of multi-epitope peptides including promising MHC class Iand II-restricted epitopes of four known Leishmania infantum proteins. Front Immunol (2014) 5:268. doi:10.3389/fimmu.2014.00268

Conflict of Interest Statement: The authors declare that the research was conducted in the absence of any commercial or financial relationships that could be construed as a potential conflict of interest.

Received: 14 March 2014; accepted: 24 July 2014; published online: 22 August 2014.
Citation: Joshi S, Rawat K, Yadav NK, Kumar V, Siddiqi MI and Dube A (2014) Visceral leishmaniasis: advancements in vaccine development via classical and molecular approaches. Front. Immunol. 5:380. doi: 10.3389/fimmu.2014.00380

This article was submitted to Immunotherapies and Vaccines, a section of the journal Frontiers in Immunology.

Copyright () 2014 Joshi, Rawat, Yadav, Kumar, Siddiqi and Dube. This is an openaccess article distributed under the terms of the Creative Commons Attribution License (CC BY). The use, distribution or reproduction in other forums is permitted, provided the original author(s) or licensor are credited and that the original publication in this journal is cited, in accordance with accepted academic practice. No use, distribution or reproduction is permitted which does not comply with these terms. 